\title{
State Reach and Development in Africa since the 1960s: New Data and Analysis
}

\author{
Carl Müller-Crepon* \\ University of Oxford
}

November 17, 2021

\begin{abstract}
Prominent arguments hold that African states' geography limits state capacity, impedes public service provision, and slows economic development. To test this argument, I collect comprehensive panel data on a proxy of local state capacity, travel times to national and regional capitals. These are computed on a yearly $5 \times 5 \mathrm{~km}$ grid using time-varying data on roads and administrative units (1966-2016). I use these data to estimate the effect of changes in travel times to capitals on local education provision, infant mortality rates, and nightlight emissions. Within the same location, decreases in travel times to its capitals are robustly associated with improved development outcomes. The article advances the measurement of state capacity and contributes to understanding its effects on human welfare.
\end{abstract}

*email: carl.muller-crepon@politics.ox.ac.uk. University of Oxford, Department for Politics and International Relations. I thank Lukas Dick and Benjamin Füglister for excellent research assistance. I am grateful to two anonymous reviewers, Lars-Erik Cederman, Robert Bates, Simon Hug, Philipp Hunziker, Horacio Larreguy, Clara Neupert-Wentz, Yannick Pengl, Ryan Saylor, and audiences at the APSA Annual Meeting 2019, the AFK workshop in Hamburg, and ETH Zurich for very helpful comments and feedback. 


\section{Introduction}

Adverse population distributions, arbitrary colonial borders, and deficient transport networks limit state capacity in Africa and are blamed to impede good governance and economic development on the continent (e.g., Herbst 2000). However, empirical tests of this reasoning lag behind its frequent use as we lack geographically disaggregated and time-varying data on African states' capacity to estimate its effect on local development. This research note introduces such panel data on local state capacity proxied by travel times to regional and national capitals. With these data, I document a generally positive, robust association between improving local state capacity and development.

The new data of state capacity builds on previous measures that have, after an initial focus on the country-level (Hendrix 2010), captured important subnational variation in state capacity (Boone 2003). However, their reliance on either surveys (Wig and Tollefsen 2016) or age-heaping in censuses (Lee and Zhang 2017) limits spatio-temporal coverage and availability in low-capacity states. As a remedy, I develop a continent-wide, yearly proxy of local state capacity based on travel times to post-independence regional and national capitals between 1966 and 2016. ${ }^{1}$ I compute these travel times for a $5 \times 5 \mathrm{~km}$ grid of the continent using new panel data on administrative geographies and road networks digitized from the Michelin map corpus. The data is validated with information on local state capacity from the Afrobarometer (2018).

I use the new data to estimate the effect of local state capacity on development. Previous studies provide cross-sectional evidence that locations farther away from capitals experience more conflict (e.g. Tollefsen and Buhaug 2015), suffer from corruption (Campante and Do 2014; Krishna and Schober 2014), and exhibit lower levels of development (Acemoglu, García-Jimeno and Robinson 2015; Henn 2020), an effect that is historically persistent (Pierskalla, Schultz and Wibbels 2017). ${ }^{2}$ I address potential cross-sectional endogeneity of administrative geographies by focusing on variation within locations and country-years. I find that reductions in travel times to capitals are associated with increases in education and infant survival rates, as well as nightlight emissions. These results are not explained by spurious migration, differential pre-trends, endogenous road construction, improvements in economic market access, or ethnic favoritism and conflict.

\footnotetext{
${ }^{1}$ Available at https://github.com/carl-mc/state_reach_africa.

${ }^{2}$ Similarly, historical post offices fostered development in the US (Rogowski et al. 2019).
} 


\section{State capacity and development}

State capacity denotes states' ability to enforce their will by monitoring and steering citizens' behavior (Mann 1984; Migdal 1988). It consists of their administrative capacity, military strength, and ability to tax individuals (Hendrix 2010). Physical access to citizens through transport infrastructure is a key determinant of state capacity (Acemoglu, García-Jimeno and Robinson 2015; Boulding 1962; Herbst 2000; Mann 1984).

Four mechanisms link physical accessibility via local state capacity to development. First, low transport costs between states' headquarters and the population enables bureaucrats and police officers to enforce law and order, thereby triggering the developmental effects of centralized state institutions (Campante and Do 2014; Huntington 1968). Second, states' provision of services such as health care and education depends on their capability to monitor demand and control agents, both of which increases with local state capacity (Krishna and Schober 2014; Henn 2020). In addition, citizens' access to specialized services (e.g., hospitals and courts) increases near the administrative capitals that typically harbor them. Third, smooth local accessibility increases citizens knowledge of and ability to tap into private rents from the state such as public sector jobs or subsidies (Ades and Glaeser 1995; Banerjee et al. 2018).

A fourth mechanism that links state capacity with citizens' welfare consists of taxation. As states become locally more capable, they are able to collect more taxes, which will, ceteris paribus, decreases citizens' material welfare. With that, the net effect of state capacity depends on whether the exchange of taxes for state-provided good is generally beneficial for citizens (Timmons 2005) or not (Scott 2017). While unable to disentangle the above theorized four mechanisms, the empirical analysis below sheds light on the overall effect of state capacity on local development.

\section{Approximating state reach}

Because physical accessibility is a necessary (but not sufficient) condition for state capacity, I proxy local state reach with the weighted sum of travel times to a locations' national 
and regional capitals: ${ }^{3}$

$$
\begin{aligned}
& \text { total state reach } \text { ret }_{p, t}=\sum_{u=1}^{U} \omega_{u} \text { state reach } \text { ru, }_{p, t} \\
& =\sum_{u=1}^{U}-\omega_{u} \ln \left(1+d_{t}\left(p, C_{p, u, t}\right)\right)
\end{aligned}
$$

where state reach on a level of administrative hierarchy $u$ towards point $p$ at time $t$ is calculated as the travel time (in hours) on the shortest path between $p$ and its capital $C_{p, u, t}$ on the road network at time $t^{4}$ The log-transform ${ }^{5}$ captures the convex relation between travel times to capitals and state capacity (Figure 2). Weights $\omega_{u}$ denote the impact of times to capitals on level $u$. Because $\omega_{u}$ likely vary across different state activities, I estimate $\omega_{u}$ for each development outcome separately. I measure state reach ${ }_{p, u, t}$ with time-varying data on regional and national administrative geographies and road networks. ${ }^{6}$

First, I collect comprehensive panel data on the boundaries and capitals of first-level (regional) administrative units since African countries' independence. Drawing on diverse secondary sources, the dataset covers 1763 unique region-periods between independence and 2016 (Appendix A). Data on national borders and capitals comes from Cshapes (Weidmann and Gleditsch 2010). Changes in administrative unit designs and capital locations lead to temporal variation in state reach ${ }_{p, u, t}$.

Second, I transform the corpus of Michelin road maps into a digital road atlas akin to a time-varying Google Maps. ${ }^{7}$ Scanned maps are available at a scale of 1:4 million ${ }^{8}$ for 23 years between 1966 and 2014. Following Müller-Crepon, Hunziker and Cederman (2021), pixels that depict roads are classified with the fully convolutional neural network, vectorized, and transformed into a planar graph that covers the African landmass at a resolution of .0417 decimal degrees $(\approx 5 \mathrm{~km}$; Appendix B). Each edge on the network is associated with a travel time derived from the quality of roads observed on the Michelin maps. With these data on roads and administrative units, I can compute the travel

\footnotetext{
${ }^{3}$ No panel data exists on $2^{\text {nd }}$ or $3^{\text {rd }}$ level administrative units.

${ }^{4}$ The relation of travel times with state capacity likely varies by country. This can be reflected by normalizing travel times by country characteristic $x_{c}$. The country-year fixed effects in the analysis constitute such a normalization because $\log \left(\left(1+d_{t}\left(p, C_{p, u, t}\right)\right) / x_{c}\right)$ decomposes to $\log \left(1+d_{t}\left(p, C_{p, u, t}\right)\right)-\log \left(x_{c}\right)$.

${ }^{5}$ Adding 1 hour prevents taking the log of 0 in capitals.

${ }^{6}$ Surpassing rail or air transport, road transport is the dominant motorized transport mode in Africa (Jedwab and Storeygard 2018).

${ }^{7}$ Jedwab and Storeygard (2018) use the Michelin maps to measure economic market access.

${ }^{8}$ This corresponds to $1 \mathrm{~mm}$ per $4 \mathrm{~km}$ and puts an upper precision limit on the data.
} 


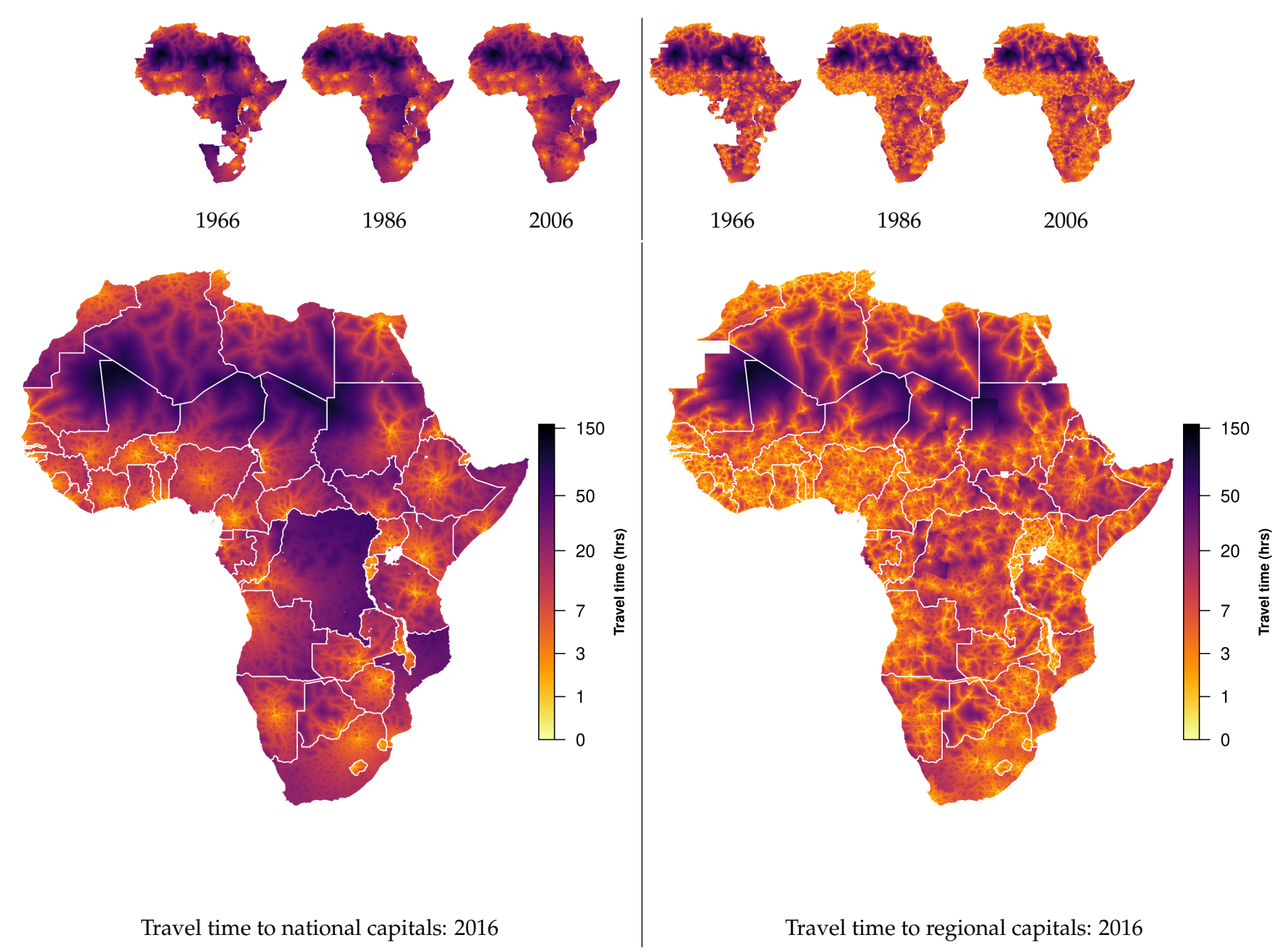

Figure 1: State reach in Africa, 1966-2016. 

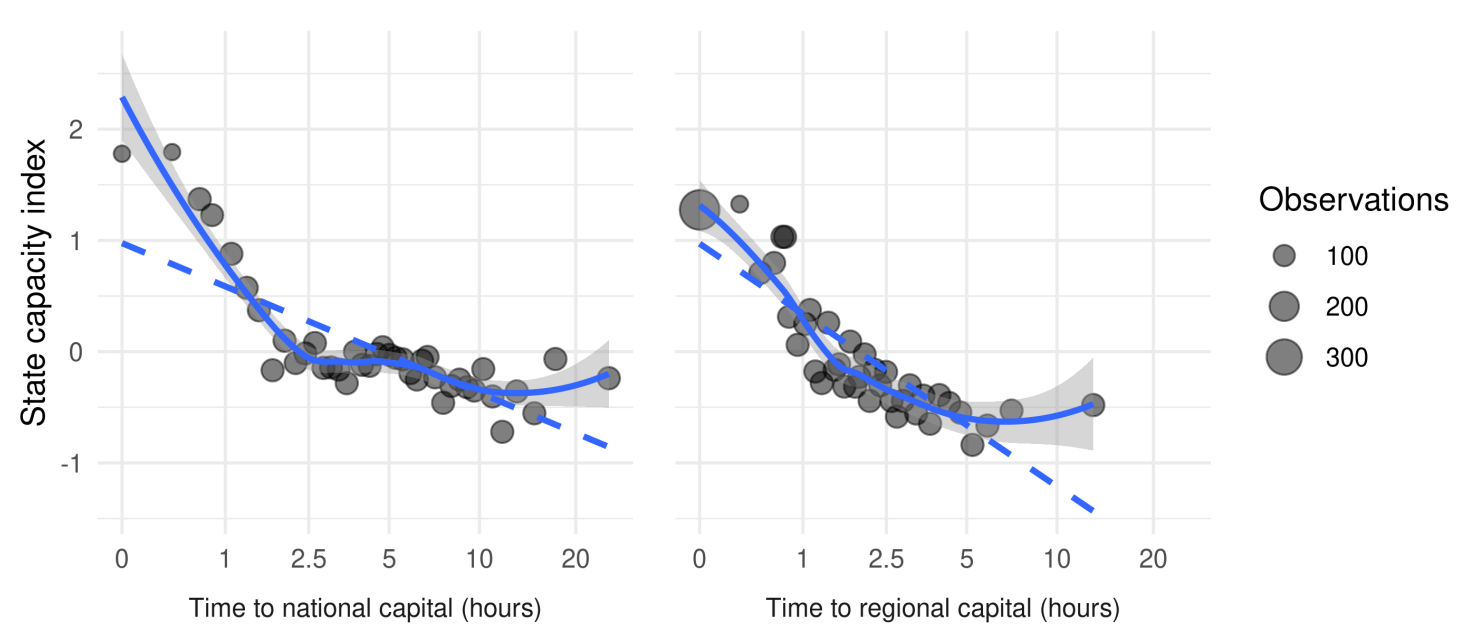

Figure 2: Travel times to national and regional capitals and state capacity index Values are demeaned by country $\times$ survey round and averaged within $40 \mathrm{x}$-axis quantiles.

time on the shortest path from each location in Africa to its corresponding national and regional capitals in a given year. Doing so results in the measure state reach ${ }_{p, u, t}$ for the grid cells of an Africa-wide raster with a .0417 decimal degree resolution for every year between 1966 and 2016 depicted in Figure 1.

I validate the data as a proxy for local state capacity using a state capacity index constructed from data on Afrobarometer's (2018) enumeration areas. The survey provides geocoded data on the presence of the police and military, post offices, schools, and hospitals, as well as public services such as water, sewage, and electricity. I aggregate this information via the first component of a Principal Component Analysis, capturing $36.2 \%$ of the data's variation. Figure 2 shows that travel times to capitals correlate strongly with the resulting state capacity index. Travel times also fit the index better than mere geodesic, as-the-crow-flies distances (Appendix C.1). In sum, travel times to capitals are a valid proxy of local state capacity.

\section{State reach in Africa: weak, growing, and unequal}

African states' reach has increased since their independence (Figure 3). Travel times between national capitals and citizens have decreased from a 1966 average of 11.7 hours to 9.3 hours in 2016, a change of 20.3 percent. Travel times to regional capitals decreased from 5.1 hours to 3.5 hours.

Three trends underlie this development (Appendix C.2). First, administrative geographies have changed. Côte d'Ivoire, Nigeria, and Tanzania have relocated their national 


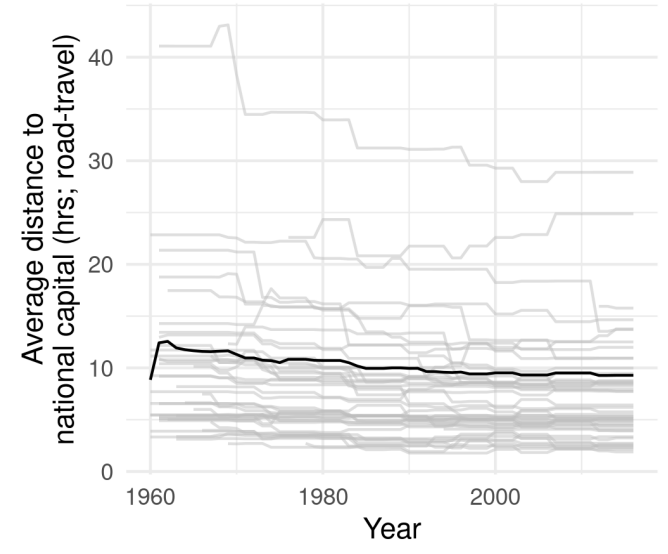

(a) Average time to national capital

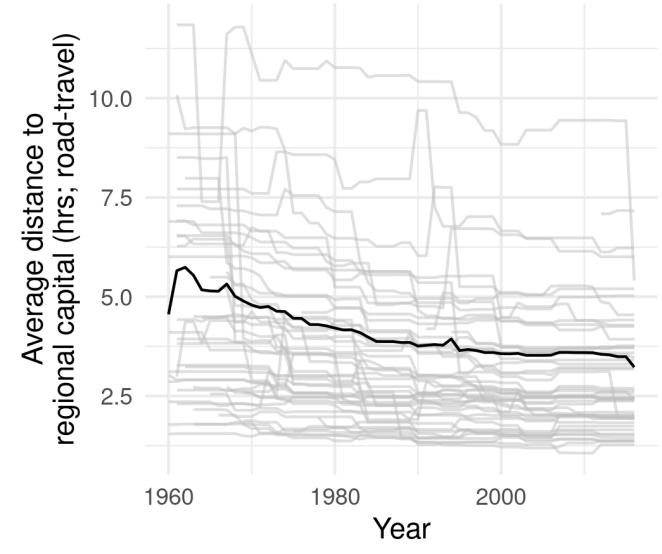

(b) Average time to regional capital

Figure 3: Decreasing travel times to regional and national capitals in Africa 1960-2015.

Population-weighted averages based on HYDE population estimates (Goldewijk, Beusen and Janssen 2010) and travel times to capitals.

capitals ${ }^{9}$ and most governments have created new administrative regions (Grossman and Lewis 2014; Grossman, Pierskalla and Dean 2017). ${ }^{10}$ Second, transport infrastructure has improved, with quality-weighted mileage increasing by about 50 percent since independence. Lastly, many citizens moved closer to capitals as urbanization rates doubled from 20 to 40 percent (World Bank 2018).

The maps in Figure 1 show that travel times to capitals exhibit substantive variation within and across countries. In contrast to small Rwanda, travel times to the DR Congo's capital Kinshasa vary between 0 and 50 hours, with a high median of 34.3 hours, reflecting the country's "difficult geography" (Herbst 2000) and sparse infrastructure. Changes in travel times since 1966 are marked by similar variation. States and regions that seceded or relocated their capital experienced the largest improvements. These changes exhibit substantive spatial variation because changes in administrative geographies and road networks have spatially varying effects. My empirical strategy exploits this fact.

\section{Data on local development}

The empirical analysis examines whether changes in African states' reach affected local development, measured with data on education, infant mortality, and nightlight emis-

\footnotetext{
${ }^{9}$ Abidjan to Yamoussoukro (1983), Lagos to Abuja (1991), and Dar es Salaam to Dodoma (1974, but ministries remain in Dar es Salaam).

${ }^{10}$ Similarly, capitals of independent Eritrea and South Sudan moved closer to citizens.
} 


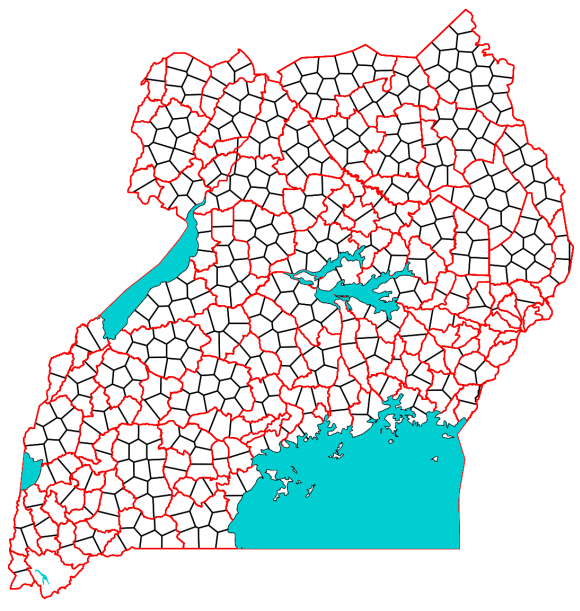

(a) Regions and Voronoi cells

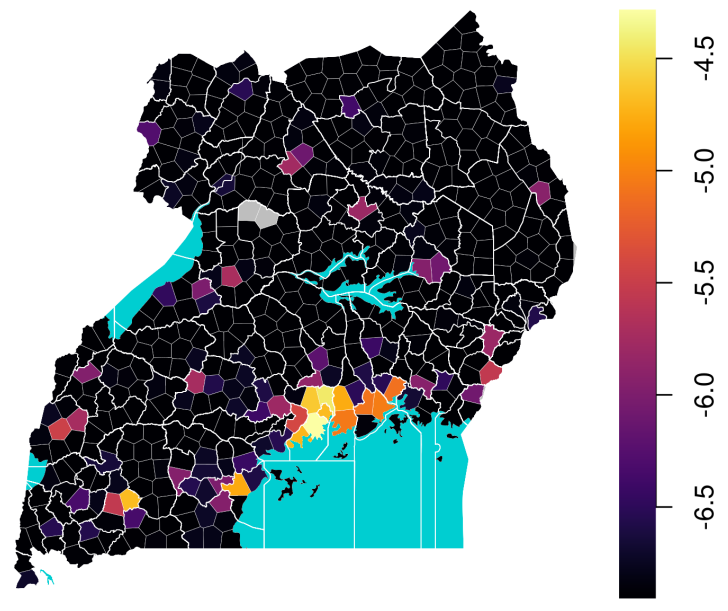

(b) Average nightlights per capita 1992-2013 (log)

Figure 4: Voronoi cells, regions, and nightlights in Uganda 1992-2013.

Panel (a) plots all regional borders between 1992 and 2013 (red) and Voronoi cells (black). Unpopulated cells in (b) in grey.

sions. ${ }^{11}$ To measure primary education, I rely on the Demographic and Health Survey (DHS 2018). The DHS encodes the educational achievement of all members of sampled households. Assuming that they live where they were raised, I model the level of education of 2.1 million individuals older than 15 as having been influenced by the travel time to their capitals at age 6. An 'attended primary school' dummy serves as the main outcome, capturing the arguably most important component of educational services and avoiding the skewed distribution of individuals' education levels. ${ }^{12}$

The DHS also measures the under-1 mortality of 2.9 million infants born to women aged 15-49. I model infants' deaths as depending on the travel time to their mothers' capitals at their birth. Infant mortality and education rates exhibit local temporal variation because children and household members sampled in the same place have been born and schooled at different times. In modeling this variation, I assume that migration decisions do not respond to changes in state reach in a manner that correlates with the observed outcomes and show that results hold among non-migrants.

To mitigate the uneven survey coverage and counter concerns about migration biases, I also proxy local development with nightlight emissions (Weidmann and Schutte 2017) derived from satellite images (1992-2013; National Geophysical Data Center 2014).

\footnotetext{
${ }^{11}$ Appendix D.2 provides summary statistics.

${ }^{12}$ Appendix E.6 shows robustness across different education levels.
} 
I measure nightlights within centroidal Voronoi cells $\left(400 \mathrm{~km}^{2}\right)^{13}$ that are nested within administrative regions (Figure 4 and Appendix D.1). In contrast to quadratic cells that frequently overlap with (changing) administrative borders, travel times can be consistently aggregated to the Voronoi cells. Nightlights are log-transformed after adding a constant of $.001 .^{14}$

\section{Empirical strategy}

The empirical analysis estimates the effect of travel times to capitals on local development. To account for any cross-sectional endogeneity from, e.g., strategic road, capital, and border placements and geographical confounders, I only study temporal variation in travel times and development within the same location:

$$
Y_{i, p, c, t, s}=\alpha_{p}+\lambda_{c, t}+\mu_{s}+\beta_{1} \text { time to nat. } \text { cap. }_{p, t}+\beta_{2} \text { time to reg. } \text { cap }_{p, t}+\delta X_{i}+\epsilon_{i, p, c, t},
$$

where $\beta_{1}$ and $\beta_{2}$ are the effects associated with travel times to point $p$ 's regional and national capitals at time $t$. In parallel to weights $\omega_{u}$ in Equation 1, the sum of $\beta_{1}$ and $\beta_{2}$ proxies the total effect of state capacity. The units of analysis $i$ are individuals in the education and infant mortality analyses and Voronoi cells in the examination of nightlight emissions. DHS respondents $i$ are nested in location $p$ and year $t \cdot{ }^{15} p$ is synonymous with $i$ where Voronoi cells are the units of analysis. The model controls for all constant attributes of locations/Voronoi cells, country-years, and surveys through fixed effects $\alpha_{p}$, $\lambda_{c, t}$, and $\mu_{s}$. Individual-level controls $X_{i}$ in the education models consist of respondents' sex, age and its square. Infant mortality models include mothers' age at birth and its square, infants' birth-order and its square, as well as female and twin dummies. I add no time-varying covariates to the baseline nightlight model. I cluster standard errors on the point and country-year levels.

Relying on this two-way fixed effect estimator, ${ }^{16}$ I assume that changes in travel times to capitals are exogenous to local development outcomes observed thereafter. Robustness checks account for potential violations of this assumption, in particular non-parallel

\footnotetext{
${ }^{13}$ Results are robust to varying cell sizes (Appendix E.7).

${ }^{14}$ I drop cells with oil wells that cause bright flares of burning gas (Lujala, Rød and Thieme 2007).

${ }^{15}$ In the individual-level analyses, locations $p$ are the grid cells from the $5 \times 5 \mathrm{~km}$ travel time raster. The DHS's random displacement of clusters by up to 10 (2) kilometers in rural (urban) areas adds noise.

${ }^{16}$ The 'treatments' are continuous, time-variant travel times and do not suit a binary difference-indifference designe.
} 
trends, endogenous roadbuilding, spurious correlations with changes in economic market access, or potential omitted variables such as ethnic inclusion or civil war.

\section{Results}

The results show that reductions in travel times towards regional and national capitals are, first, robustly associated with increasing primary education rates. Second, infant mortality rates improve as travel times to national, but not regional capitals decrease. Lastly, nightlight emissions significantly increase with declining travel times to regional capitals. Their relation to changes in the time to national capitals is of roughly similar size but statistically more unstable. Interpreting the sums of $\beta_{1}$ and $\beta_{2}$ as total effect of state capacity reveals its consistently positive, meaningful, and statistically significant association with local development.

Table 1: Changes in time to national/regional capital and local development

\begin{tabular}{|c|c|c|c|}
\hline & $\begin{array}{c}\text { Primary educ. }(0 / 100) \\
\text { (1) }\end{array}$ & $\begin{array}{c}\text { Infant mort. }(0 / 100) \\
(2)\end{array}$ & $\begin{array}{c}\text { Light/capita (log) } \\
\text { (3) }\end{array}$ \\
\hline Time to nat. capital (log) & $\begin{array}{l}-2.667^{* * *} \\
(0.400)\end{array}$ & $\begin{array}{l}0.878^{* * *} \\
(0.233)\end{array}$ & $\begin{array}{l}-0.052^{* *} \\
(0.026)\end{array}$ \\
\hline Time to reg. capital (log) & $\begin{array}{l}-1.253^{* * *} \\
(0.305)\end{array}$ & $\begin{array}{l}0.203 \\
(0.145)\end{array}$ & $\begin{array}{l}-0.037^{* *} \\
(0.019)\end{array}$ \\
\hline$\beta_{1}+\beta_{2}:$ & $\begin{array}{c}-3.92^{* * *} \\
(0.465)\end{array}$ & $\begin{array}{l}1.082^{* * *} \\
(0.262)\end{array}$ & $\begin{array}{l}-0.089^{* * *} \\
(0.028)\end{array}$ \\
\hline Point FE: & yes & yes & yes \\
\hline Country-year FE: & yes & yes & yes \\
\hline Survey FE: & yes & yes & - \\
\hline Controls: & yes & yes & - \\
\hline Mean DV: & 70 & 9.6 & -6.5 \\
\hline Observations & $2,091,736$ & $2,895,564$ & $1,507,013$ \\
\hline Adjusted $\mathrm{R}^{2}$ & 0.452 & 0.051 & 0.836 \\
\hline
\end{tabular}

Table 1 presents the baseline results. Interpreting coefficients in substantive terms, Model 1 indicates that a reduction of travel times to national (regional) capitals from 2 to 1 hours is associated with a precisely estimated increase in primary education rates by 1.1 (.54) percentage points. Model 2 shows that infant mortality rates decrease by .38 percentage points when the time to the national capital decreases from 2 to 1 hours. 


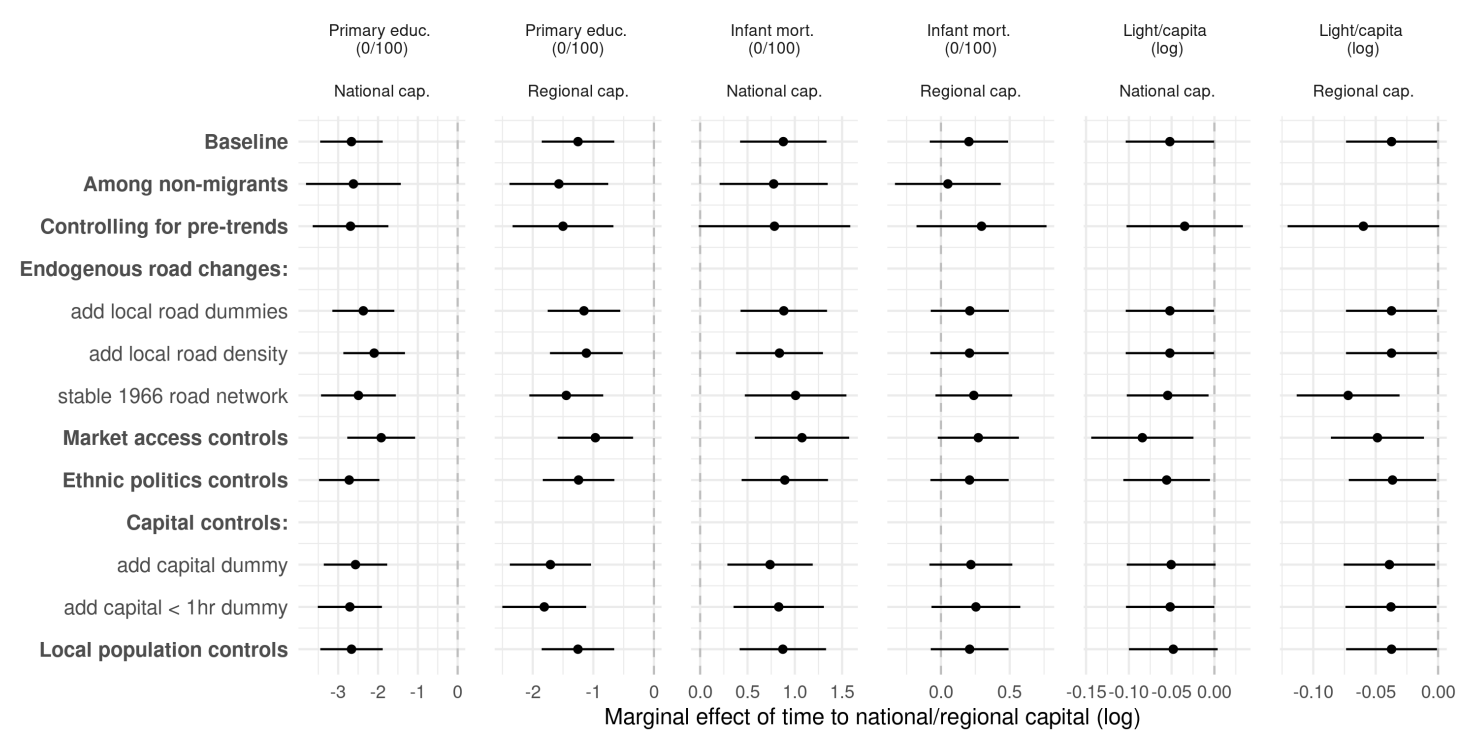

Figure 5: Robustness checks. Coefficient estimates with 95\% CIs.

In contrast, there is no evidence for a meaningful association of infant mortality with regional capital accessibility. The respective coefficient is close to zero and statistically insignificant.

Distinguishing the effects of relocations of national capitals ${ }^{17}$ from those of road network changes reveals that national capital relocations primarily drive the effects on education and infant mortality rates (Appendix E.1). Changes due to road networks have a smaller, but statistically significant effect on primary education and no effect on infant mortality.

Lastly, Model 3 yields a significant association of travel times to regional capitals with nightlight emissions. As the local distance to the regional capital decreases from two to one hours, per-capita nightlight emissions increase by 1.8 percent. The same change in the distance to its national capital is associated with a similar increase in nightlights, which is however affected by differential pre-trends (Appendix E.3). The estimate's noisiness is related to the short coverage of the data (1992-2013) with changes of national capitals in newly independent South Sudan (2013) and Eritrea (1992), each with only one pre-/ post-treatment year. Thus, changes in road networks with their more diffuse impact on development drive the estimate.

Figure 5 presents the results of robustness checks fully discussed in Appendix E. First, I find that the effects of travel times to capitals hold among non-migrant DHS respon-

\footnotetext{
${ }^{17}$ There are very few regional capital relocations.
} 
dents. Second and evidence against reverse causality, I find no significant effect of differential pre-trends, except for those that affect the nightlight model. Third, the results are not caused by potentially endogenous road building accounted for by time-varying local road density-measures or by computing travel times on time-invariant road data from 1966. Fourth, a potentially spurious correlation of travel times to capitals with economic market access to the 1530 biggest African cities does not drive the results. Fifth, the results are not due to potential omitted variables, in particular ethno-political inclusion, exposure to ethnic civil wars, regional and national capital dummies, and population density controls. Lastly, Appendix E.6 demonstrates robustness across alternative outcome specifications.

These analyses suggest generally positive developmental effects of increases in state capacity as proxied by estimated aggregate effects of travel times to national and regional capitals. Where national and regional administrations move closer to the citizens they govern, education rates improve. Infant mortality rates increase with travel times to national but not regional capitals. Lastly, nightlights become brighter when regional capitals move closer. Pre-trends partially drive the developmental effects of closer national capitals on nightlights, raising concerns about reverse causality.

\section{Conclusion}

One important constraint of states' capacity and their ability to foster development is their physical access to the population (Herbst 2000). Measuring African states' varying success in making their citizens accessible, this research note has introduced new spatio-temporal data on travel times between administrative capitals and citizens as a proxy for post-colonial state capacity. The new data shows a generally positive association between increases in local state capacity on various indicators of citizens' wealth and well-being. Difficult geographies with hard-to-access populations thus impede governance and economic development on the continent. At the same time, the results reject geographic determinism since states can and do improve their reach and thereby foster local development.

Offering new data and empirical results, this research note opens up avenues for future research. A first set of questions concerns the effects of state capacity on different state-provided goods and under different institutional settings. Second, there might be 
important heterogeneity in the mechanisms through which and when local state capacity matters most for citizens' welfare. Crises such as droughts, floods, or violent conflicts may exacerbate the effects of weak statehood. Lastly, researchers could use the new measure of state capacity to study state-society interactions more generally, ranging from resource extraction, over accountability, to conflict processes. 


\section{References}

Acemoglu, Daron, Camilo García-Jimeno and James A. Robinson. 2015. "State Capacity and Economic Development: A Network Approach." American Economic Review 105(8):2364-2409.

Ades, Alberto F. and Edward L. Glaeser. 1995. "Trade and Circuses: Explaining Urban Giants." Quarterly Journal of Economics 110(1):195-227.

Afrobarometer. 2018. "Afrobarometer Data." Available at http://www.afrobarometer.org .

Banerjee, Abhijit, Rema Hanna, Jordan Kyle, Benjamin A. Olken and Sudarno Sumarto. 2018. "Tangible Information and Citizen Empowerment: Identification Cards and Food Subsidy Programs in Indonesia." Journal of Political Economy 126(2):451-491.

Boone, Catherine. 2003. Political Topographies of the African State. Cambridge: Cambridge University Press.

Boulding, Kenneth. 1962. Conflict and Defense. Lanham: University Press of America.

Campante, Filipe R. and Quoc Anh Do. 2014. "Isolated capital cities, accountability, and corruption: Evidence from US States." American Economic Review 104(8):2456-2481.

DHS. 2018. "Demographic and Health Surveys." Integrated Demographic and Health Series (IDHS), version 2.0, Minnesota Population Center and ICF International. Available at http://idhsdata.org .

Goldewijk, Kees Klein, Arthur Beusen and Peter Janssen. 2010. “Long-term dynamic modeling of global population and built-up area in a spatially explicit way: HYDE 3.1." The Holocene 2010(1):1-9.

Grossman, Guy, Jan H. Pierskalla and Emma Boswell Dean. 2017. “Government Fragmentation and Public Goods Provision." Journal Of Politics 79(3):823-839.

Grossman, Guy and Janet I. Lewis. 2014. "Administrative Unit Proliferation." American Political Science Review 108(01):196-217.

Hendrix, Cullen S. 2010. "Measuring state capacity: Theoretical and empirical implications for the study of civil conflict." Journal of Peace Research 47(3):273-285.

Henn, Sören. 2020. "Complements or Substitutes? How Institutional Arrangements Bind Chiefs and the State in Africa." Unpublished Working Paper. http://soerenhenn.com/files/Henn_Chiefs.pdf .

Herbst, Jeffrey. 2000. States and Power in Africa. Princeton: Princeton University Press.

Huntington, Samuel P. 1968. Political Order in Changing Societies. New Haven: Yale University Press. 
Jedwab, Remi and Adam Storeygard. 2018. "The Average and Heterogeneous Effects of Transportation Investments: Evidence from Sub-Saharan Africa 1960-2010." Unpublished Working Paper.

Krishna, Anirudh and Gregory Schober. 2014. "The Gradient of Governance: Distance and Disengagement in Indian Villages." Journal of Development Studies 50(6):820-838.

Lee, Melissa M. and Nan Zhang. 2017. "Legibility and the Informational Foundations of State Capacity." The Journal of Politics 79(1):118-132.

Lujala, Päivi, Jan Ketil Rød and Nadja Thieme. 2007. "Fighting over Oil: Introducing a New Dataset." Conflict Management and Peace Science 24(3):239-256.

Mann, Michael. 1984. "The autonomous power of the state: its origins, mechanisms and results." European Journal of Sociology 25(2):185-213.

Migdal, Joel S. 1988. Strong societies and weak states: state-society relations and state capabilities in the Third World. Princeton: Princeton University Press.

Müller-Crepon, Carl, Philipp Hunziker and Lars-Erik Cederman. 2021. "Roads to Rule, Roads to Rebel: Relational State Capacity and Conflict in Africa." Journal of Conflict Resolution 65(2-3):563-590.

National Geophysical Data Center. 2014. "DMSP-OLS Nighttime Lights Time Series, Version 4." Electronic resource. Available at http://ngdc.noaa.gov/eog/dmsp/ downloadV4composites.html. .

Pierskalla, Jan, Anna Schultz and Erik Wibbels. 2017. “Order, Distance, and Local Development over the Long-Run." Quarterly Journal of Political Science 12(4):375-404.

Rogowski, Jon C, John Gerring, Matthew Maguire and Lee Cojocaru. 2019. "Public Infrastructure and Economic Development: Evidence from Postal Systems." American Journal of Politicial Science, forthcoming .

Scott, James C. 2017. Against the Grain. A Deep History of the Earliest States. New Haven: Yale University Press.

Timmons, Jeffrey F. 2005. “The Fiscal Contract: States, Taxes, and Public Services." World Politics 57(4):530-567.

Tollefsen, Andreas Forø and Halvard Buhaug. 2015. "Insurgency and inaccessibility." International Studies Review 17(1):6-25.

Weidmann, Nils B and Sebastian Schutte. 2017. “Using night light emissions for the prediction of local wealth." Journal of Peace Research 54(2):125-140.

Weidmann, Nils and Kristian Skrede Gleditsch. 2010. "Mapping and Measuring Country Shapes: The cshapes Package." R Journal 2(1):18-24. 
Wig, Tore and Andreas Forø Tollefsen. 2016. "Local institutional quality and conflict violence in Africa." Political Geography 53:30-42.

World Bank. 2018. "World Development Indicators." Accessed on 2019/03/20 from https://databank.worldbank.org/data . 


\section{Supporting Information}

\section{State Reach and Development in Africa since the 1960s: New Data and Analysis}

\section{Table of Contents}

A Regions in post-colonial Africa . . . . . . . . . . . . . . . . . . . A2

B Road data from the Michelin map corpus . . . . . . . . . . . . . . . . A4

B.1 The Michelin map corpus . . . . . . . . . . . . . . . . . . . . . . A4

B.2 Map digitization . . . . . . . . . . . . . . . . . . . . . . . A5

B.3 Retrieving travel speeds . . . . . . . . . . . . . . . . . . . A5

B.4 Network construction . . . . . . . . . . . . . . . . . . . . . . A6

C Travel times to capitals as proxy for state reach: Data description and validation . . . . . . . . . . . . . . . . . . . . . . . . . . . . . A7

C.1 Validation . . . . . . . . . . . . . . . . . . . . . A7

C.2 Description . . . . . . . . . . . . . . . . . . . A7

D Data and summary statistics . . . . . . . . . . . . . . . . A13

D.1 Units of the nightlight analysis: Voronoi cells. . . . . . . . . . . . . . A13

D.2 Summary statistics . . . . . . . . . . . . . . . . . . . . . . A16

E Robustness checks . . . . . . . . . . . . . . . . . . . . . . . A19

E.1 Re-locations of national capitals vs. road-network development: . . . . . A19

E.2 Migration . . . . . . . . . . . . . . . . . . . . . . . . . . . . . A20

E.3 Testing for pre-trends and reverse causality . . . . . . . . . . . . . . A21

E.4 Potentially endogenous road building . . . . . . . . . . . . . . . . A24

E.5 Omitted variables and spurious correlations . . . . . . . . . . . . . . A25

E.6 Varying education- and health-related outcomes: . . . . . . . . . . . . A30

E.7 Additional robustness checks: . . . . . . . . . . . . . . . . . . . . A31

F References . . . . . . . . . . . . . . . . . . . A34 


\section{A Regions in post-colonial Africa}

To collect a full panel on the borders and capitals of first-level administrative regions in Africa since countries' independence, I draw on the qualitative accounts of unit changes from the statoids.com database and encode each administrative unit change geographically. I therefore rely primarily on maps from the GAUL database, (FAO 2014). Although this data is contemporary (reaching back until 1990), it allows me to trace back all unit-splits - this type of unit-change constitutes the vast majority of cases - by simply merging the units observed after the split which results in the original unit. Where units have been merged or the administrative map of a country has been redrawn completely, I make use of more than 100 digitized maps, mostly from the CIA Base Map series as well as other GIS data, such as the GADM database. Each region-period is associated with its capital, as listed in most cases by statoids. com. Missing capitals are searched on the maps and in secondary sources. The capitals are then geocoded using the geonames . org gazetteer. Changes in the location of capitals within the same boundaries of a region naturally result in new region-periods. Each region-period is associated with a start and end-year. To ensure consistent and temporally non-overlapping coding, region-periods that start after January $1^{\text {st }}$ are coded as starting in the next year. The final data set covers 1763 unique region-periods, covering each African country from independence to 2016. The evolution of the number of regions in the data set is traced in Figure A1. Figure A2 plots the data for the year 2016.

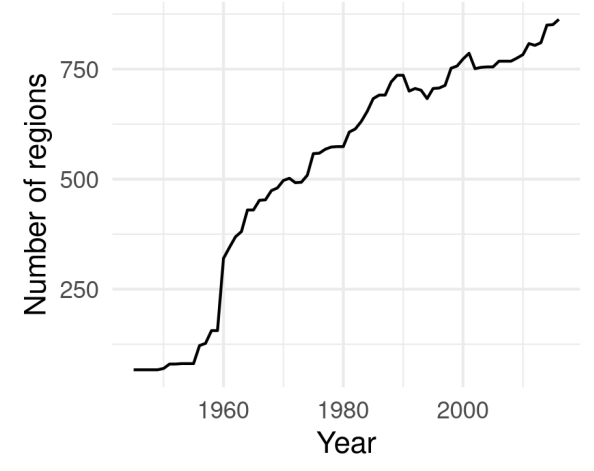

(a)

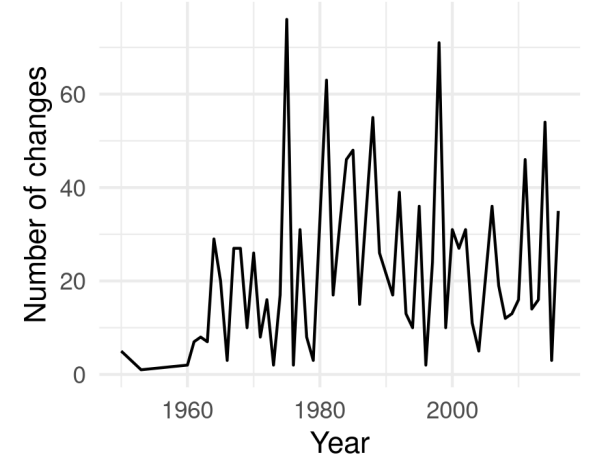

(b)

Figure A1: Description of newly collected data on first-level administrative units in Africa. 


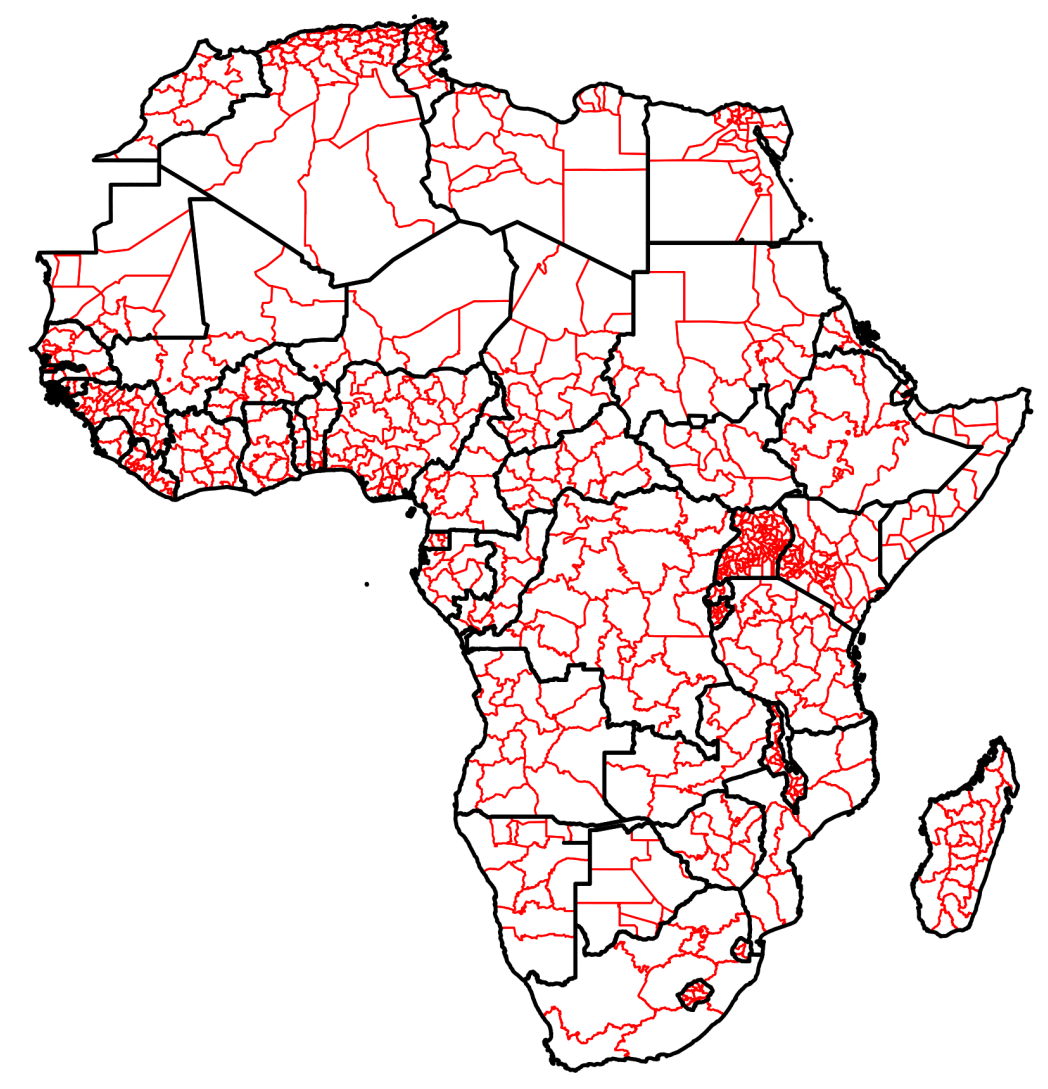

(a) First-level administrative units in Africa 2016

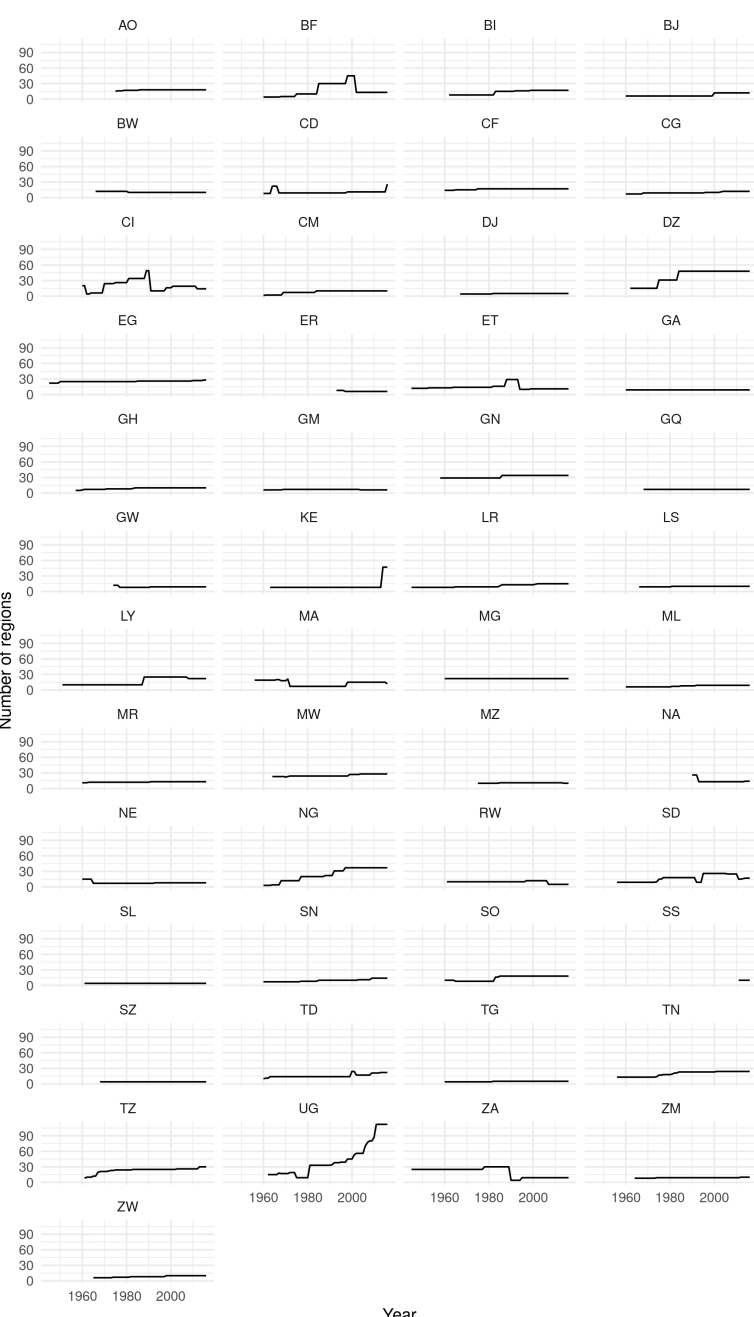

(b) Number of admin-1 units by country and year

Figure A2: Overview over first-level administrative unit data. 


\section{B Road data from the Michelin map corpus}

This section provides the details on how I digize the Michelin map corpus, building on the procedure that was developed by Müller-Crepon, Hunziker and Cederman (2021). Compared to Müller-Crepon, Hunziker and Cederman (2021), data collection has been extended for the purpose of this article from the initial 6 to 23 road map cross-sections. Subsection B.1 describes the map corpus, Subsection B. 2 summarizes the digitization procedure, Subsection B.3 describes the construction of travel speeds, and Subsection B.4 discusses the construction of the final road network data.

\section{B.1 The Michelin map corpus}

The source for road network data for post-colonial Africa is the African Michelin map corpus, a collection of large topographical maps at a resolution of 1:4,000,000. Each map shows detailed information on road infrastructure with a consistent cartographic symbology for about a third of the continent (see Figure A3). While coverage before the 1960s is sporadic, Michelin has covered the entire African continent at intervals of approximately 5 years beginning in 1964 (see Figure A4). This makes the Michelin corpus an unparalleled source for time-variant road-network information. I digitize 34 map sheets published between 1964 and 2017, which combine into 23 maps of the entire continent.

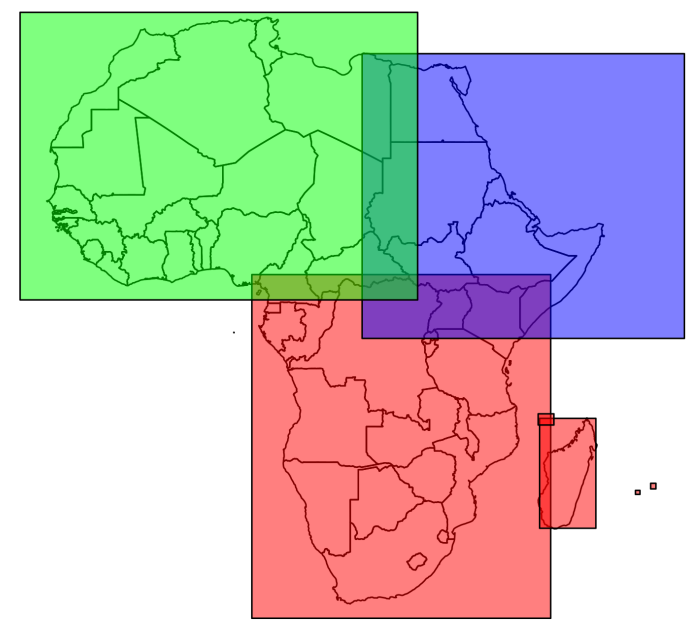

Figure A3: Spatial coverage of Michelin Map types.

Note that Madagascar is not covered in 1966. Green: North-West. Blue: North-East. Red: Center-South. 


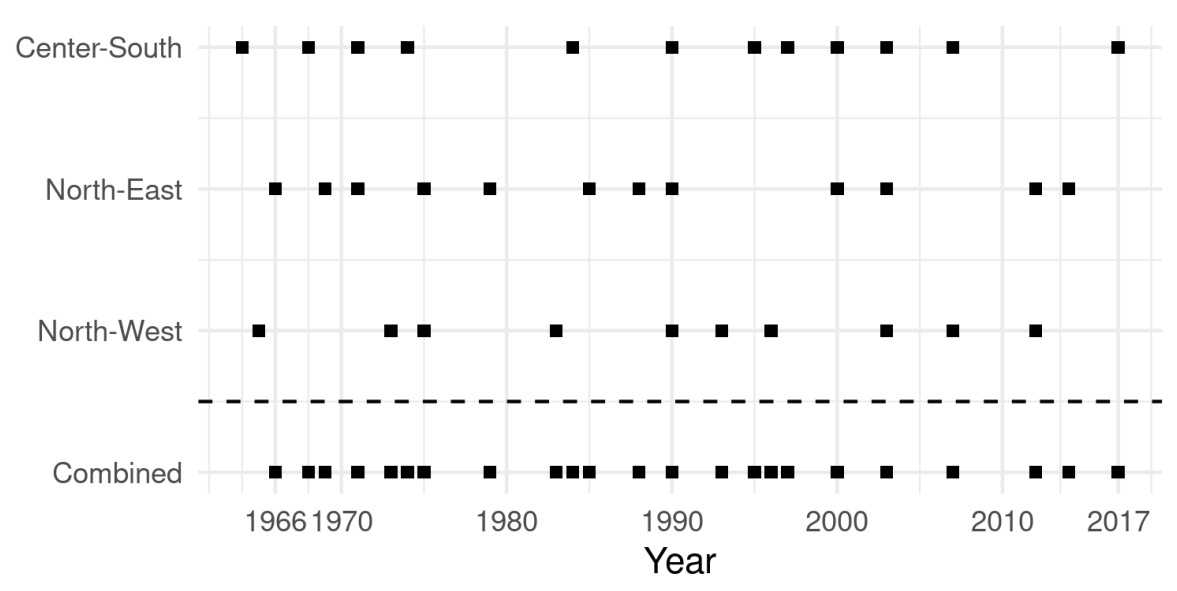

Figure A4: Temporal coverage of Michelin Maps

\section{B.2 Map digitization}

I use the Fully Convolutional Neural Network (FCNN) and post-processing algorithms developed by Müller-Crepon, Hunziker and Cederman (2021) to transform the scanned and georeferenced Michelin Maps into spatial road network data. In short, the FCNN is based on the methodology developed by Shelhamer, Long and Darrell (2017) and yields pixel-level predictions of road-types for the map scans. These predictions are fed into a four-step algorithm to transform pixels into vector data by (1) thinning lines made up of pixels, (2) tracing lines to transform them into vectors, (3) filling small, unlikely gaps in the resulting network of lines, and (4) smoothing road-type information to reduce noise from small missclassifications. Müller-Crepon, Hunziker and Cederman (2021) demonstrate that the procedure yields an excellent digitization of road networks: over $98.8 \%$ of all extracted roads are present in the Michelin maps, and $98.6 \%$ of all Michelin roads are extracted. Taking road categories into account, the respective percentages are somewhat lower, but still 88.8 and 96.4, respectively. Ordinal missclassification errors are however small, on average (among errors) amounting to 1.38 on the ordinal 6-point road-type scale. These errors will thus only marginally affect travel time estimates and will do so in a presumably random manner.

\section{B.3 Retrieving travel speeds}

I follow Müller-Crepon, Hunziker and Cederman (2021) and use their travel speeds for each of the six main road categories in the Michelin data ${ }^{18}$ from the Michelin website (www.viamichelin.com. For each road category, they collect data on a random selection of trips on roads of that category, and record the travel speed returned by the Michelin querying tool. Traveling speed on foot-paths is defined as $6 \mathrm{~km}$ (about 4 miles) per hour. This corresponds to walking-time estimates on www. maps.google.com (see

\footnotetext{
${ }^{18}$ The 16 types of roads in the Michelin data are collapsed into the 6 main categories.
} 
also Jedwab and Storeygard 2018).

\section{B.4 Network construction}

I transform the road data from the Michelin map corpus into planar graphs that uniformly cover geographic space. I do so in a step-wise manner, following again the procedure developed by Müller-Crepon, Hunziker and Cederman (2021):

1. Foot-path network: The basis of the planar graphs consist of network of 8-connected 'foot-paths.' The graph's nodes are the centroids of a raster of population estimates from the HYDE 3.1 data (Goldewijk, Beusen and Janssen 2010) for 1960 at a resolution of .04167 ×.04167 decimal degrees (or ca. $5 \mathrm{~km}$ at the equator). Each node is connected with a foot-path to its 8 nearest neighbors using queen moves. This setup allows for much more flexible applications than travel-query APIs such as Google Maps which do not process queries from/to points that are too distant from the next road.

2. Adding roads: I then overlay the basic foot-path network with the spatial lines extracted from each map corpus after aligning them all to the last and most extensive network observed in 2017. ${ }^{19}$ I create additional nodes wherever two roads or foot-paths cross, thus retaining the planar graph property. These additional nodes' purpose is to serve as intersections. They are not associated with any population data. Hence, travel between two populated nodes will typically start by taking a foot-path to a road, and end by traveling from a road to the target node on another foot-path. Note that the occasional imperfect spatial alignment of road networks observed in consecutive Michelin maps causes variation in the length of these first or last foot-paths of some trips. The resulting variation in travel travel times is however deemed negligible and, importantly, random.

3. Calculating edge weights: Following Müller-Crepon, Hunziker and Cederman (2021), each edge on the network is associated with an edge weight which is equivalent to the estimated time it takes to traverse the edge.

Müller-Crepon, Hunziker and Cederman (2021) demonstrate that the road networks thus constructed yield very similar travel time estimates as the Google Maps API.

\footnotetext{
${ }^{19}$ This alignment is necessary to preclude small 'jumps' in the location of roads, caused by the digitization procedure, to introduce random noise into the measure and downwards bias the estimation results. The alignment of roads is computed via ArcGIS's align_feature function.
} 


\section{Travel times to capitals as proxy for state reach: Data descrip- tion and validation}

\section{C.1 Validation}

I use data from the Afrobarometer (2018) surveys to validate travel times to national and regional capitals as proxies for subnational state capacity. In particular, the surveys contain information provided by the enumerators about the presence of state organs and services in each enumeration area (EA). The respective items range from the local provision of electricity, water and sewage, over the presence of a school, clinic, or post office, to the presence of police and military forces. All variables are coded as dummies. I combine them into a joint index of local state capacity by taking their first principal component, which explains 36.2 percent of the variation in its constitutive parts. Furthermore, I compute for each EA the time to its regional and national capital at the time of the survey. ${ }^{20}$

Figure A5 plots the association between EA's travel times to their regional and national capital and each indicator, demeaned by country. All indicators correlate with travel times to capitals, which I take as a first indication of their quality as proxies for local state capacity.

Table A1 goes a step further and compares the association between travel times and the local state capacity index with the correlation between mere geodesic distances to capitals. The results show that both distance measures correlate with the index. However, once both are included in Models 3 and 6, the coefficient of geodesic distances becomes much smaller and looses significance in Model 3. I take this as evidence that travel times are superior to simply taking geodesic distances. After all, state agents typically rely on earth bound vehicles and do not fly as crows.

\section{C.2 Description}

Three main factors influence the difficulties of a state to reach out to its population: the location of administrative borders and capitals, and the structure of the transportation network that links the state to its subjects, and the geographic distribution of its population. By changing their geography along each of these three dimensions, states can increase their reach and improve their capacity to govern. First, states can optimize the location of its headquarters, open new branches of state agencies, and shift the boundaries of administrative units (Fesler 1949). Since independence, the Côte d'Ivoire, Nigeria, and Tanzania have relocated their national capitals ${ }^{21}$ and most have increased the number of administrative units (Figure A6a, see also Grossman and Lewis 2014; Grossman, Pierskalla and Dean 2017). ${ }^{22}$ Similarly, the independence of Eritrea and South Sudan has

\footnotetext{
${ }^{20}$ To do so, I use the geocodes provided by Ben Yishay, Ariel Rotberg et al. (2017).

${ }^{21}$ Côte d'Ivoire (Abidjan to Yamoussoukro in 1983), Nigeria (Lagos to Abuja in 1991), and Tanzania (Dar es Salaam to Dodoma in 1974). The change in Tanzania was less de facto than de jure. Until today, all ministries are located in Dar es Salaam.

${ }^{22}$ Note the case of Uganda being the outlier with the steepest increase in Figure A6a.
} 

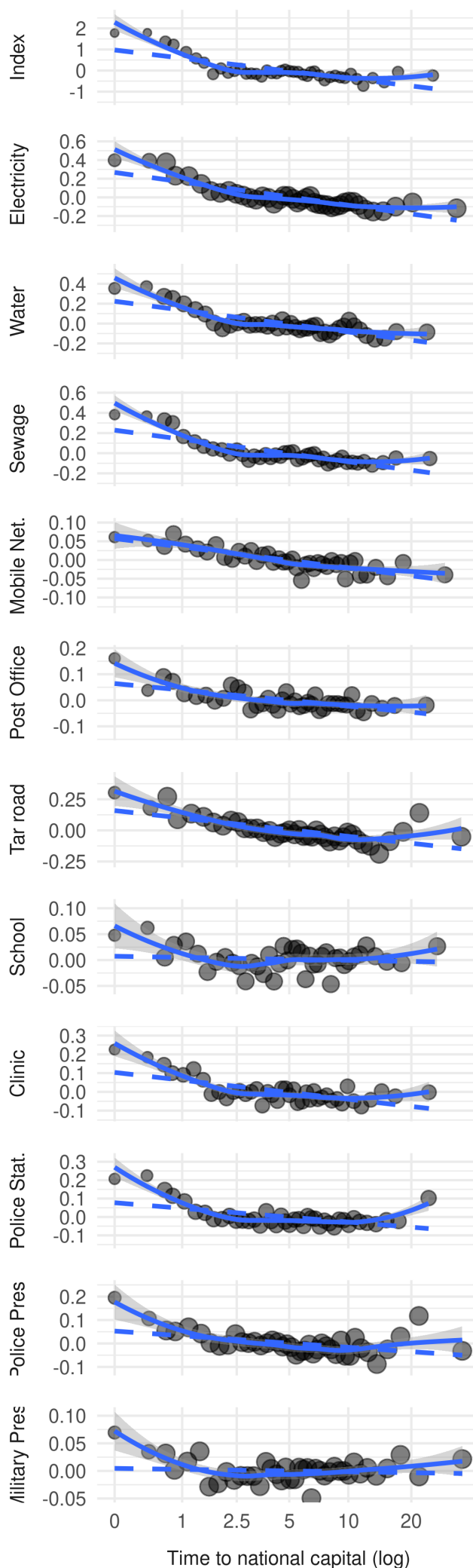
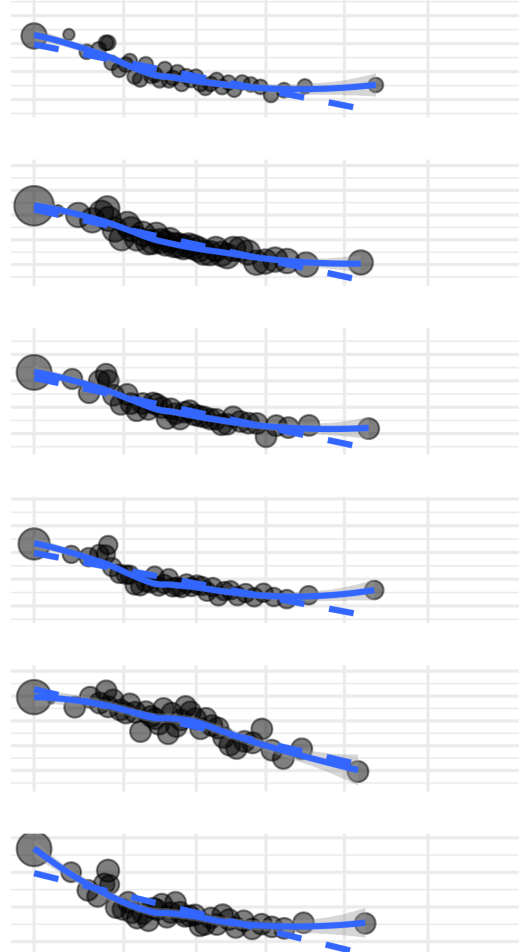

Observations

- 250

500
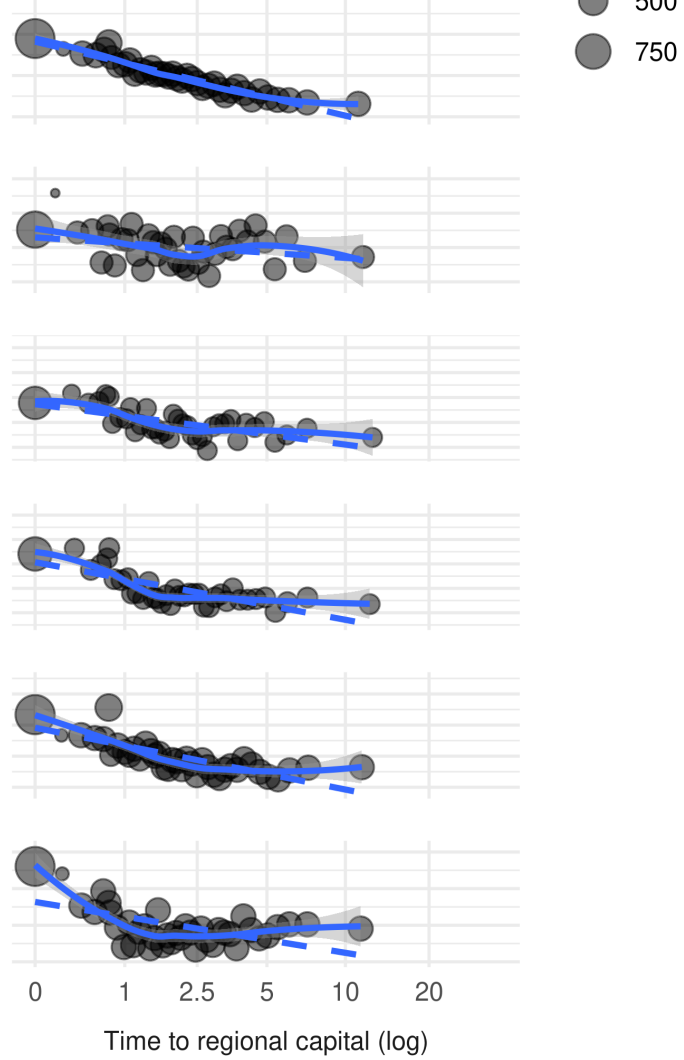

Figure A5: Correlation between travel times to national and regional capitals and state capacity index

The state capacity index is constructed from enumeration area level data in the Afrobarometer survey. The plot shows values of the index that are demeaned by country $\times$ survey round and averaged within 40 quantiles of the travel time to regional and national capitals. 
Table A1: Logged distances to national and regional capitals correlate with state capacity index

\begin{tabular}{|c|c|c|c|c|c|c|}
\hline & \multicolumn{6}{|c|}{ State capacity index } \\
\hline & (1) & (2) & (3) & (4) & (5) & (6) \\
\hline Nat. capital: geodesic & $\begin{array}{c}-0.295^{* * *} \\
(0.037)\end{array}$ & & $\begin{array}{c}-0.026 \\
(0.056)\end{array}$ & & & \\
\hline Nat. capital: time & & $\begin{array}{c}-0.635^{* * *} \\
(0.080)\end{array}$ & $\begin{array}{c}-0.588^{* * *} \\
(0.117)\end{array}$ & & & \\
\hline Reg. capital: geodesic & & & & $\begin{array}{c}-0.414^{* * *} \\
(0.029)\end{array}$ & & $\begin{array}{c}-0.199^{* * *} \\
(0.043)\end{array}$ \\
\hline Reg. capital: time & & & & & $\begin{array}{c}-1.006^{* * *} \\
(0.059)\end{array}$ & $\begin{array}{c}-0.608^{* * *} \\
(0.080)\end{array}$ \\
\hline Unit: & EA & EA & EA & EA & EA & EA \\
\hline Survey FE: & yes & yes & yes & yes & yes & yes \\
\hline Mean DV: & -0.0042 & -0.0042 & -0.0042 & -0.0042 & -0.0042 & -0.0042 \\
\hline Std.-dev. DV: & 2 & 2 & 2 & 2 & 2 & 2 \\
\hline Observations & 11,302 & 11,302 & 11,302 & 11,302 & 11,302 & 11,302 \\
\hline Adjusted $\mathrm{R}^{2}$ & 0.311 & 0.317 & 0.317 & 0.348 & 0.351 & 0.356 \\
\hline
\end{tabular}

reduced the distance between their population and the capital. ${ }^{23}$

Second, states can improve transport networks to access certain areas. Although the main backbones of African road networks are of colonial origin, the networks' extent has increased by about 50 percent since independence (Figure A6b). While this figure is not necessarily impressive (Herbst 2000), it has shortened the distance between states and their citizens.

Lastly, states can incentivize their population to concentrate and urbanize, thereby increasing governments' economies of scale of reaching out to a particular populated place (e.g. Scott 2017). While in 1960 only about $20 \%$ of Africans have lived in cities, the proportion of urban residents in 2016 has risen above 40\% (Figure A6c). Among other social changes brought about by this development, rural-urban migrants experience a steep increase in state reach since administrations and state institutions are typically based in cities. Equivalent state-led population concentration also occurred in the countryside. In particular villagization programs, such as the resettlement of millions of Tanzanians into so-called 'Ujamaa-Villages' in the 1970s (e.g. Miguel 2004), have made rural populations more accessible to the state.

Together, administrative unit changes, road building, and population concentration since the 1960s have decreased the distance between the state's headquarters and citizens, thereby extending states' reach over the continent. As seen in Figure A7, the average travel time between African national capitals and citizens has decreased from 11.7 hours in 1966 to 9.3 hours in 2016, a change of about 20.3 percent. Moving to the level of regional administrations where changes in the design of units are more common, we observe a

\footnotetext{
${ }^{23}$ Their independence of course also affected other dimensions of the distance between the state and citizens, in particular the ethnic distance.
} 


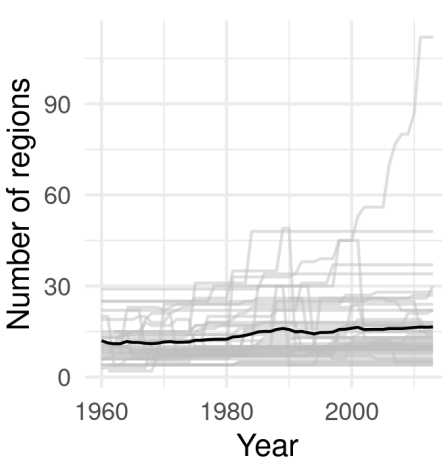

(a) Number of administrative regions

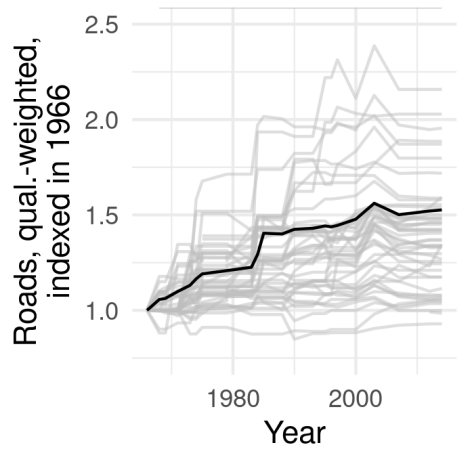

(b) Quality-weighted road mileage in Africa

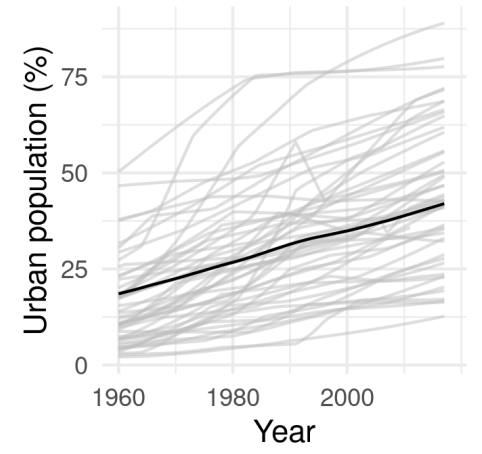

(c) Urban population

Figure A6: Drivers of expanding state reach in Africa 1960-2015.

Sources: (a) own data; (b) Michelin road map corpus; (c) World Development Indicators (World Bank 2018).

steeper trend. While citizens in 1966 had an average travel time of 5.1 hours to their regional capital, they had to travel 'only' 3.5 hours in 2016 - a decrease of 32.2 percent.

As expected from the large diversity of countries and their geographies, these continentwide aggregates mask substantial heterogeneity across and within states. Figure A9 visualizes this variation and plots population-weighted densities of travel times to national capitals for five countries in 2016 and their change since 1966. From a cross-sectional perspective, Subfigure A9a shows how states differ in their reach towards their population. Capitals of countries with "difficult geographies" (Herbst 2000) and poor infrastructure such as the DR Congo are farthest away from their median inhabitant (34.3 hours). In the mid-range, we find Mali where one travels 7.2 hours from Bamako to the median citizen. Lastly, capitals of small countries such as Rwanda naturally are closest to their median citizen (2.6 hours). Similar variation marks changes in the accessibility of the population since 1966 (Subfigure A9b). Here, the populations of states that seceded (Eritrea, Namibia, and South Sudan) and of those that relocated their capital (Nigeria, Côte d'Ivoire, Tanzania) profited the most. Other states, such as the DR Congo, significantly improved their reach in absolute term. However, in relative terms, these improvements look less impressive.

Even more striking than the variation across countries is the variation observed within countries. The density plots in Subfigure A9a visualize high levels of inequality in state reach in some countries. In particular states that Herbst (2000) associates with 'difficult geographies ${ }^{24}$ exhibit large variation in travel times - to the point where the distribution of travel times in the DR Congo is heavier in its right than left tail. Similarly, new roads, borders, and capitals do not have a geographically uniform effect. For example, relocating the Nigerian capital from Lagos to Abuja in 1991 increased state reach towards the northern areas of the country, while decreasing it around Lagos in the southwest (Figure

\footnotetext{
${ }^{24}$ Angola, DR Congo, Ethiopia, Mozambique, Namibia, Nigeria, Senegal, Somalia, Sudan (borders of 2000), Tanzania. Cf. Herbst (2000, p. 161).
} 
A8).

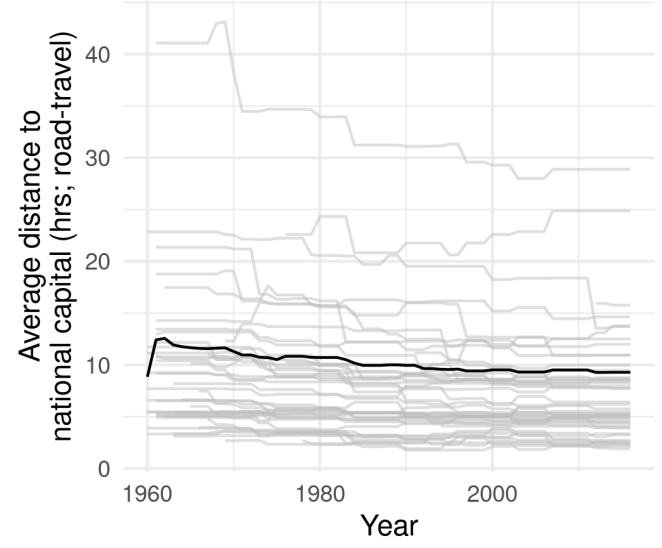

(a) Average time to national capital

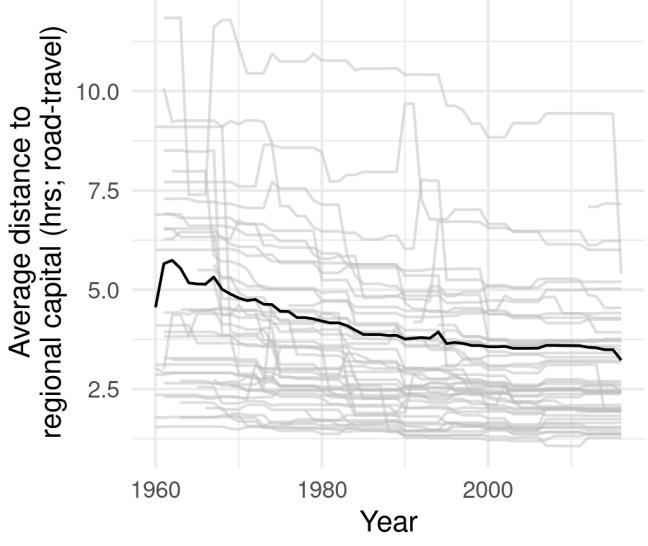

(b) Average time to regional capital

Figure A7: Decreasing travel times to regional and national capitals in Africa 1960-2015.

All averages are population weighted. Sources: Own calculations based on HYDE population estimates (Goldewijk, Beusen and Janssen 2010), Michelin-based road networks, Cshapes (Weidmann and Gleditsch 2010), and own data on administrative regions and their capitals.

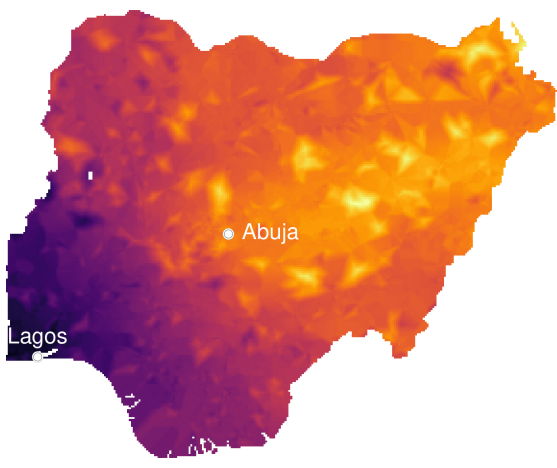

(a) Change in travel time to the national capital

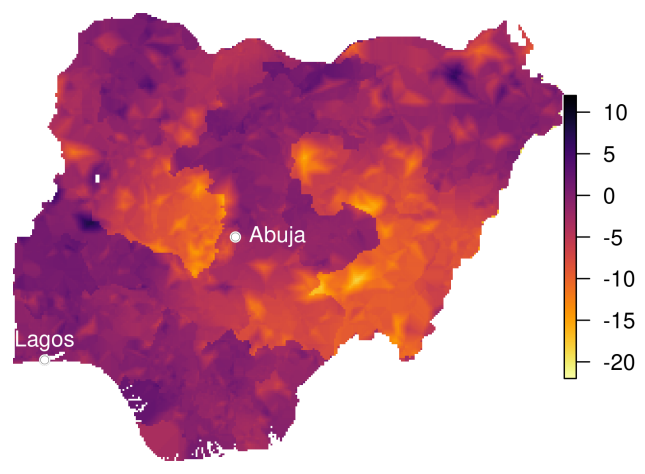

(b) ... to regional capitals

Figure A8: Change of travel times to capitals in Nigeria 1966-2016.

Note: Brighter colors indicate a decrease of travel times, thus an improvement in state reach. Sources: See Figure A7. 

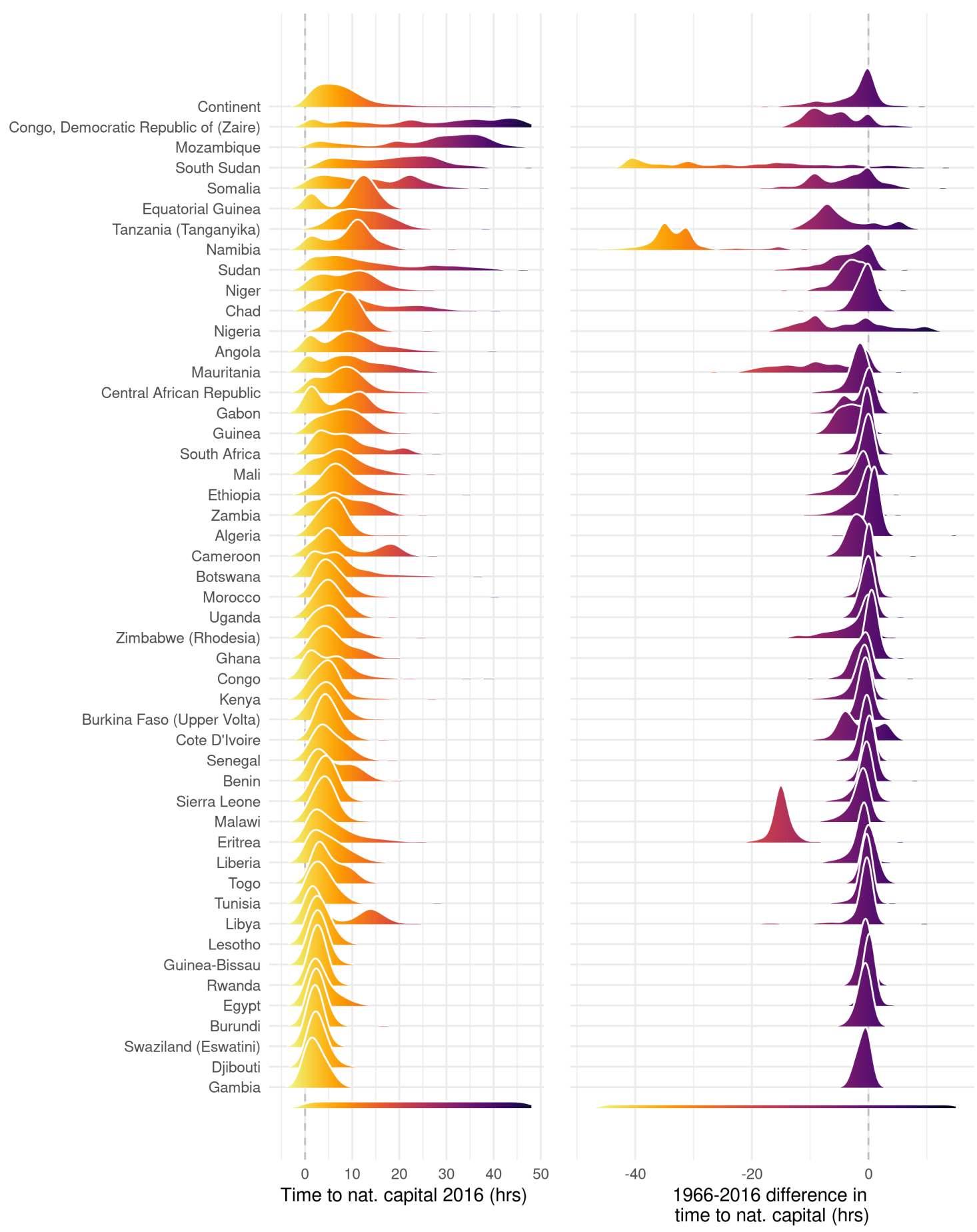

(a) Travel time to national capital 2016

(b) Change in travel time to national capital 1966-2016

Figure A9: Population-weighted distribution of state reach in Africa in 2016 and development since 1966.

Note: Brighter colors identify better outcomes. To calculate population-weighted distributions for single countries, I fix the spatial distribution of the population and the borders of countries to their status in 2016. For areas that became independent after 1966 no change can be calculated. Sources: Own calculations based on 2016 WorldPop population estimates, Michelin-based road networks, and country-borders from 2016 from Cshapes (Weidmann and Gleditsch 2010). 


\section{Data and summary statistics}

\section{D.1 Units of the nightlight analysis: Voronoi cells}

In order to divide an arbitrary geographical space into units of roughly equal size and high levels of compactness (i.e. similarity to a circle), ${ }^{25}$ this section introduces a spatial clustering algorithm that is combines the advantages of the k-means clustering algorithm (Lloyd 1982) that requires a finite sample of points to cluster, and the Voronoi tesselation that is used to transform the centers of the k-means clusters into continuous areas. The algorithm proceeds as follows:

1. Draw a large number of points $P$ from the area of polygon $t$ in set $T$. $T$ is defined in the present application as the constitutive parts of all administrative regions observed between 1992 and 2013. These polygons are computed as cutting the territory of each country with all regional borders existing between 1992 and 2013. The resulting polygons are strictly nested within all regional boundaries. Points are sampled from these polygons on the basis of a raster with a resolution of $\approx 1 \mathrm{~km}$ (.01 decimal degrees).

2. Conduct a $k$-means clustering (Lloyd 1982) of points $P$ into $N$ clusters, with $N=$ $\operatorname{round}\left(A_{T} / A_{\text {target }}\right)$, thus $\mathrm{N}$ being the number of units to create so that the average area of each unit comes closest to the target size of units. For the main analysis, the target size is $400 \mathrm{~km}^{2}$, further variations are conducted in the robustness check presented below in Subsection E.7. For best results, I initialize the k-means algorithm with a random spatial sample of $N$ points from $P$.

3. Take the centroids of the clusters thus computed and conduct a Voronoi tesselation around them.

4. Crop the resulting Voronoi polygons with the target polygon $T$.

We can now compare the Voronoi cells with the more commonly used quadratic grid cells. Across various target sizes, the Voronoi cells resulting from the relatively simple (and fast) algorithm significantly improve over the quadratic grid cells, both in terms of their distribution around the target size and in terms of their level of compactness. First, Figure A11 shows that many regular quadratic grid cells are smaller than the target size - this occurs wherever a cell is cut by a regional border or the coast line. Thus, the heterogeneity in units' sizes is correlated with their closeness to the coast and border, a feature which might introduce slight bias into an analysis. Second, Figure A12 proves that Voronoi cells are much more compact than grid cells, which - as quadratic shapes and in particular where cut by borders - are shaped in a more irregular and less "circlelike" manner.

\footnotetext{
${ }^{25}$ The shape that can continuously cover an area with the highest level of compactness is the hexagon. However, where the honeycomb reaches a border, hexagonal cells must be cut or reshaped, thus deviating from the requirements of uniform size and compactness.
} 


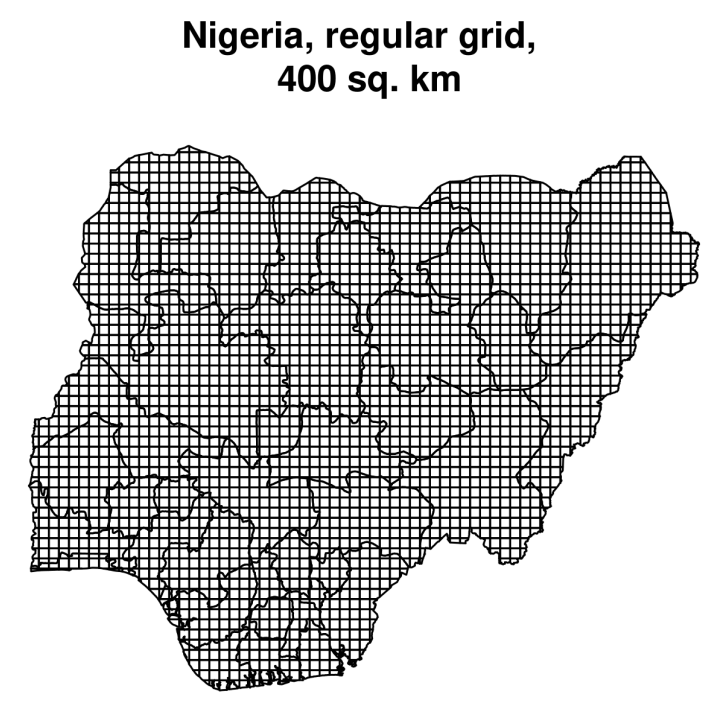

(a) Regular grid cells
Nigeria, Voronoi cells, 400 sq. $\mathrm{km}$

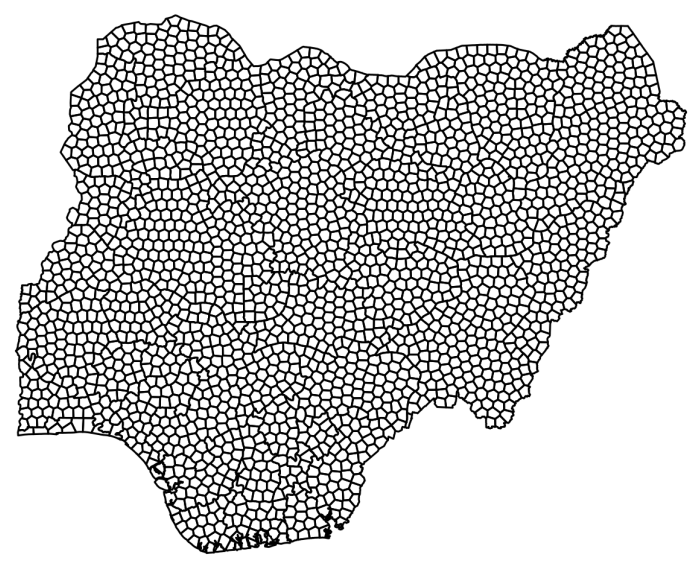

(b) Voronoi cells

Figure A10: Regular grid and Voronoi cells for Nigeria with regional borders observed in 1992-2013.

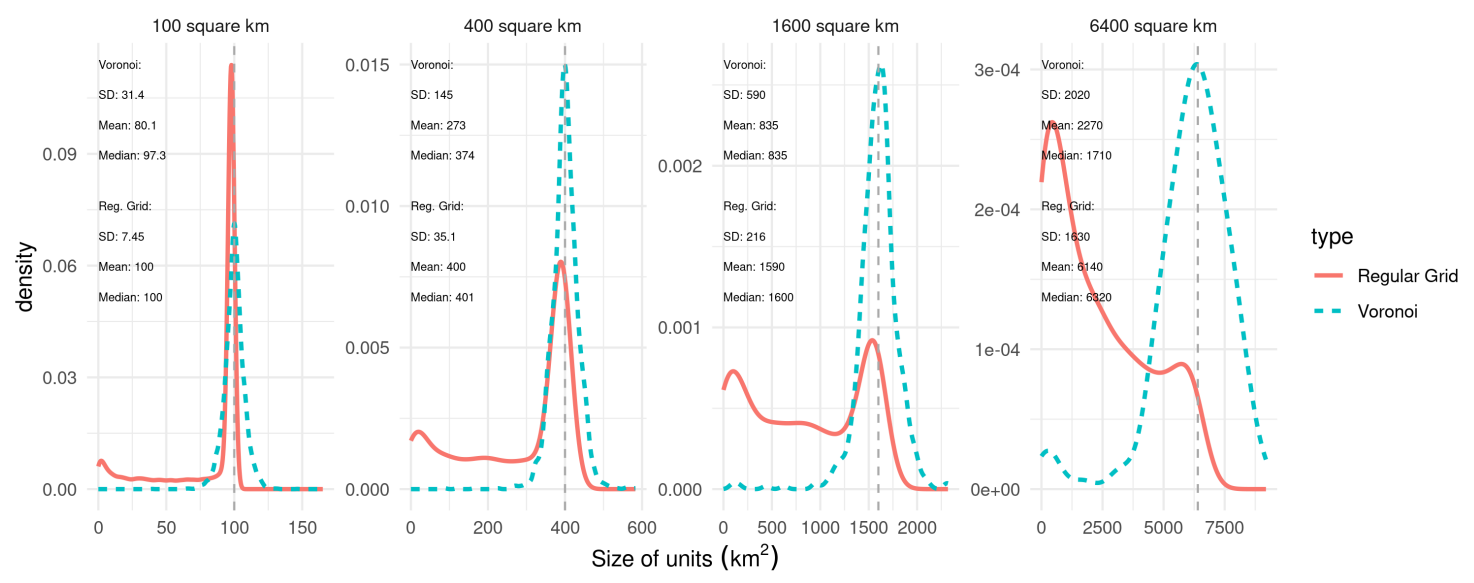

Figure A11: Size of Voronoi and regular grid cells for varying target sizes.

Vertical dashed line indicates the target size of units. Cells are constructed for all countries in mainland Africa, using borders from the year 2000. 


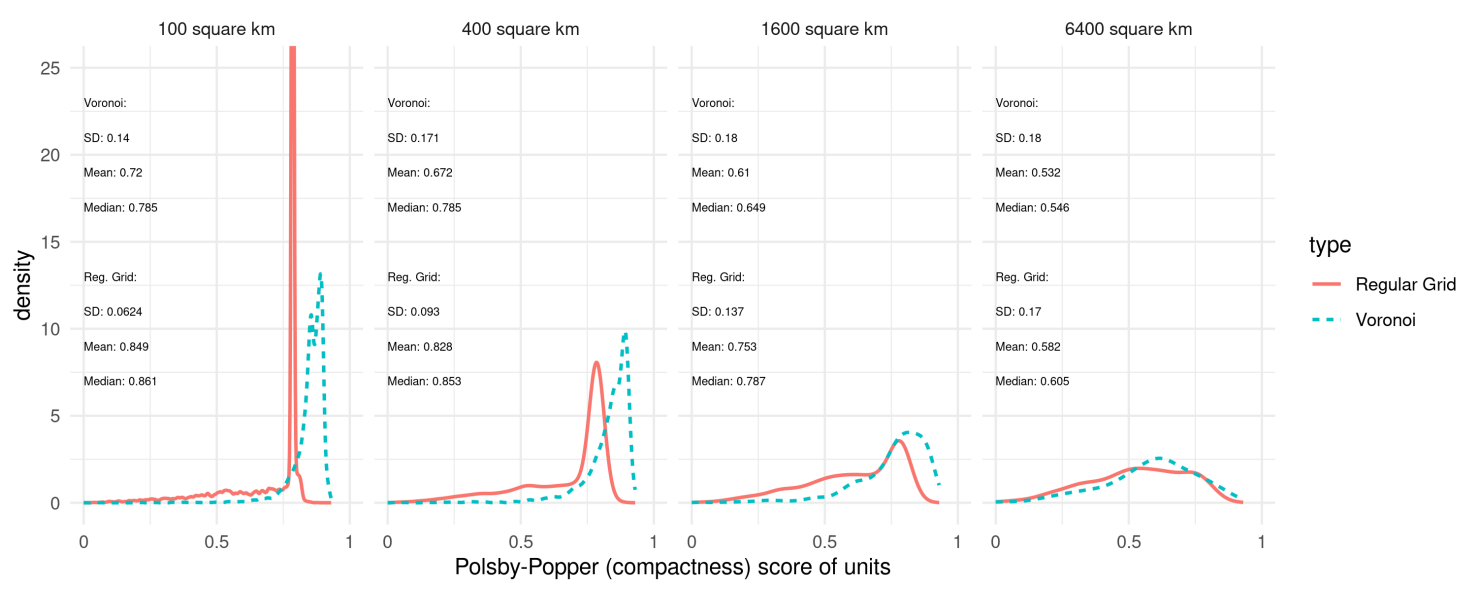

Figure A12: Compactness of Voronoi and regular grid cells for varying target sizes.

The compactness of each unit is calculated according to Polsby and Popper (1991, p. 349) as: $\left(4 \pi A_{i}\right) / P_{i}^{2}$, where $A_{i}$ is the size of unit $i$ and $P_{i}$ its perimeter. Cells are constructed for Nigeria, using regional borders observed between 1992 and 2013. Note that densities above 25 are censored to improve the readability of the graphs. 


\section{D.2 Summary statistics}

Table A2: Summary statistics: DHS education data (Personal Recode)

\begin{tabular}{lrrrrrrr}
\hline \hline Statistic & $\mathrm{N}$ & \multicolumn{7}{c}{ Mean St. Dev. } & Min & Pctl(25) & Pctl(75) & Max \\
\hline Primary educ. (0/100) & 2091736 & 70.43 & 45.64 & 0 & 0 & 100 & 100 \\
Female dummy & 2091736 & 0.53 & 0.50 & 0 & 0 & 1 & 1 \\
Age & 2091736 & 28.12 & 9.84 & 15 & 20 & 35 & 57 \\
Time to nat. capital $(\log ) 2091736$ & 1.93 & 0.80 & 0.00 & 1.40 & 2.45 & 4.50 \\
Time to reg. capital $(\log ) 2091736$ & 1.19 & 0.66 & 0.00 & 0.71 & 1.61 & 4.35 \\
\hline
\end{tabular}

Table A3: Summary statistics: DHS infant mortality data (Children Recode)

\begin{tabular}{lrrrrrrr}
\hline \hline Statistic & $\mathrm{N}$ & \multicolumn{1}{c}{ Mean } & St. Dev. & Min & Pctl(25) & Pctl(75) & Max \\
\hline Infant mort. (0/100) & 2905949 & 9.66 & 29.54 & 0 & 0 & 0 & 100 \\
Female dummy & 2905949 & 0.45 & 0.50 & 0 & 0 & 1 & 1 \\
Birth order & 2905949 & 3.31 & 2.25 & 1 & 1 & 5 & 18 \\
Twin dummy & 2905949 & 0.03 & 0.18 & 0 & 0 & 0 & 1 \\
Mother's age at birth & 2895564 & 24.61 & 6.41 & 10.00 & 20.00 & 29.00 & 49.00 \\
Time to nat. capital (log) 2905949 & 1.95 & 0.72 & 0.00 & 1.49 & 2.42 & 4.41 \\
Time to reg. capital (log) 2905949 & 1.22 & 0.62 & 0.00 & 0.78 & 1.61 & 4.35 \\
\hline
\end{tabular}

Table A4: Summary statistics: Nightlight data (Voronoi cells, $400 \mathrm{~km}^{2}$ )

\begin{tabular}{|c|c|c|c|c|c|c|c|}
\hline Statistic & $\mathrm{N}$ & Mean St & t. Dev. & Min & $\operatorname{Pctl}(25)$ & $\operatorname{Pctl}(75)$ & Max \\
\hline Light/capita (log) & 1507013 & -6.51 & 1.28 & -6.91 & -6.91 & -6.91 & 10.12 \\
\hline Time to nat. capital (log) & 1507013 & 2.92 & 0.77 & 0.26 & 2.37 & 3.52 & 4.97 \\
\hline Time to reg. capital (log) & 1507013 & 2.30 & 0.83 & 0.26 & 1.68 & 2.82 & 4.94 \\
\hline
\end{tabular}


Table A5: Samples across data sources, DHS rounds and nightlight observations

\begin{tabular}{|c|c|c|c|}
\hline Country & Adults & Children & Nightlight-cells \\
\hline Algeria & & & $1992-2013$ \\
\hline Angola & 7.1 & $6.1,7.1$ & 1992-2013 \\
\hline Benin & $4.1,6.1$ & $4.1,6.1$ & $1992-2013$ \\
\hline Botswana & & & 1992-2013 \\
\hline Burkina Faso & $2.1,3.1,4.1,6.1$ & $2.1,3.1,4.1,6.1$ & $1992-2013$ \\
\hline Burundi & $6.1,6.2,7.1$ & $6.1,6.2,7.1$ & $1992-2013$ \\
\hline Cameroon & $2.1,4.1,6.1$ & $2.1,4.1,6.1$ & $1992-2013$ \\
\hline Central African Republic & 3.1 & 3.1 & $1992-2013$ \\
\hline Chad & 7.1 & 7.1 & $1992-2013$ \\
\hline Congo - Brazzaville & & & $1992-2013$ \\
\hline Congo - Kinshasa & $5.1,6.1$ & $5.1,6.1$ & 1992-2013 \\
\hline Côte d'Ivoire & $3.1,3.2,6.1$ & $3.1,3.2,6.1$ & $1992-2013$ \\
\hline Djibouti & & & 1992-2013 \\
\hline Egypt & $\begin{array}{l}2.1,3.1,4.1,4.2 \\
5.1,5.2\end{array}$ & $\begin{array}{l}2.1,3.1,4.1,4.2, \\
5.1,5.2\end{array}$ & 1992-2013 \\
\hline Equatorial Guinea & & & $1992-2013$ \\
\hline Eritrea & & & $1993-2013$ \\
\hline Eswatini & 5.1 & 5.1 & 1992-2013 \\
\hline Ethiopia & $4.1,5.1,6.1,7.1$ & $4.1,5.1,6.1,7.1$ & $1992-2013$ \\
\hline Gabon & 6.1 & 6.1 & $1992-2013$ \\
\hline Gambia & & & $1992-2013$ \\
\hline Ghana & $\begin{array}{l}3.1,4.1,4.2,5.2 \\
7.1\end{array}$ & $\begin{array}{l}3.1,4.1,4.2,5.2 \\
7.1\end{array}$ & 1992-2013 \\
\hline Guinea & $4.1,5.1,6.1$ & $4.1,5.1,6.1$ & 1992-2013 \\
\hline Guinea-Bissau & & & $1992-2013$ \\
\hline Kenya & $4.1,5.1,7.1$ & $4.1,5.1,7.1$ & $1992-2013$ \\
\hline Lesotho & $4.1,6.1,7.1$ & $4.1,6.1,7.1$ & $1992-2013$ \\
\hline Liberia & $5.1,6.2$ & $\begin{array}{l}0.1,5.1,5.2,6.1, \\
6.2\end{array}$ & 1992-2013 \\
\hline Libya & & & 1992-2013 \\
\hline Malawi & $4.1,4.2,6.1,7.2$ & $\begin{array}{l}4.1,4.2,6.1,6.2, \\
7.2\end{array}$ & 1992-2013 \\
\hline Mali & $3.1,4.1,5.1,6.2$ & $3.1,4.1,5.1,6.2$ & 1992-2013 \\
\hline Mauritania & & & $1992-2013$ \\
\hline Morocco & 4.1 & 4.1 & $1992-2013$ \\
\hline Mozambique & $5.1,6.1,7.1$ & $6.1,7.1$ & 1992-2013 \\
\hline Namibia & $4.1,5.1,6.1$ & $4.1,5.1,6.1$ & $1992-2013$ \\
\hline Niger & $2.1,3.1$ & $2.1,3.1$ & $1992-2013$ \\
\hline Nigeria & $\begin{array}{l}2.1,4.2,5.1,6.1 \\
6.2,7.1\end{array}$ & $\begin{array}{l}2.1,4.2,5.1,6.1, \\
6.2\end{array}$ & 1992-2013 \\
\hline Rwanda & $5.1,6.1,7.1$ & $5.1,5.2,6.1,7.1$ & 1992-2013 \\
\hline Senegal & $\begin{array}{l}2.1,4.2,6.1,6.2 \\
7.2,7.3\end{array}$ & $\begin{array}{l}2.1,3.1,4.2,5.2 \\
6.1,6.2,7.2,7.3\end{array}$ & 1992-2013 \\
\hline Sierra Leone & $5.1,6.1$ & $5.1,6.1$ & 1992-2013 \\
\hline Somalia & & & 1992-2013 \\
\hline South Africa & & & $1992-2013$ \\
\hline South Sudan & & & 2011-2013 \\
\hline Sudan & & & $1992-2013$ \\
\hline Tanzania & $\begin{array}{l}4.1,4.2,5.1,6.1 \\
6.2,7.2\end{array}$ & $\begin{array}{l}4.1,5.1,6.1,6.2 \\
7.2\end{array}$ & 1992-2013 \\
\hline $\begin{array}{l}\text { Togo } \\
\text { Tunisia }\end{array}$ & $3.1,6.1$ & $0.1,3.1,6.1$ & $\begin{array}{l}1992-2013 \\
1992-2013\end{array}$ \\
\hline Uganda & $\begin{array}{l}4.1,5.1,6.1,6.2 \\
7.2\end{array}$ & $\begin{array}{l}4.1,5.1,5.2,6.1, \\
7.2\end{array}$ & 1992-2013 \\
\hline Zambia & $5.1,6.1$ & $5.1,6.1$ & 1992-2013 \\
\hline Zimbabwe & $4.1,5.1,6.1,7.1$ & $4.1,5.1,6.1,7.1$ & $1992-2013$ \\
\hline
\end{tabular}

Note that the divergence between the samples used from the DHS stems from the fact that not all surveys enlist the level of education of household members or come with the Child Recode file needed to derive infant mortality rates. 


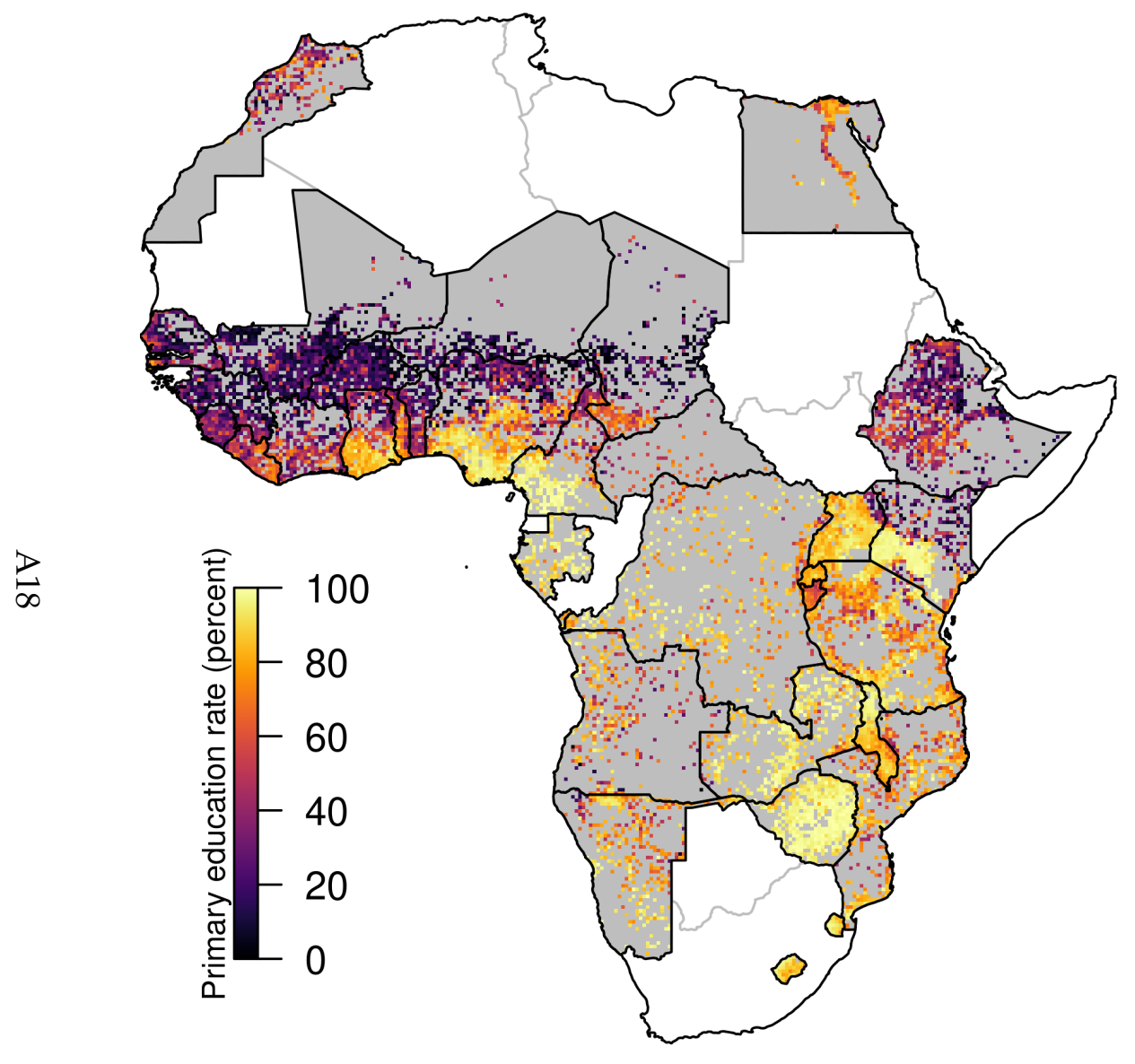

(a) Primary education rate in sample

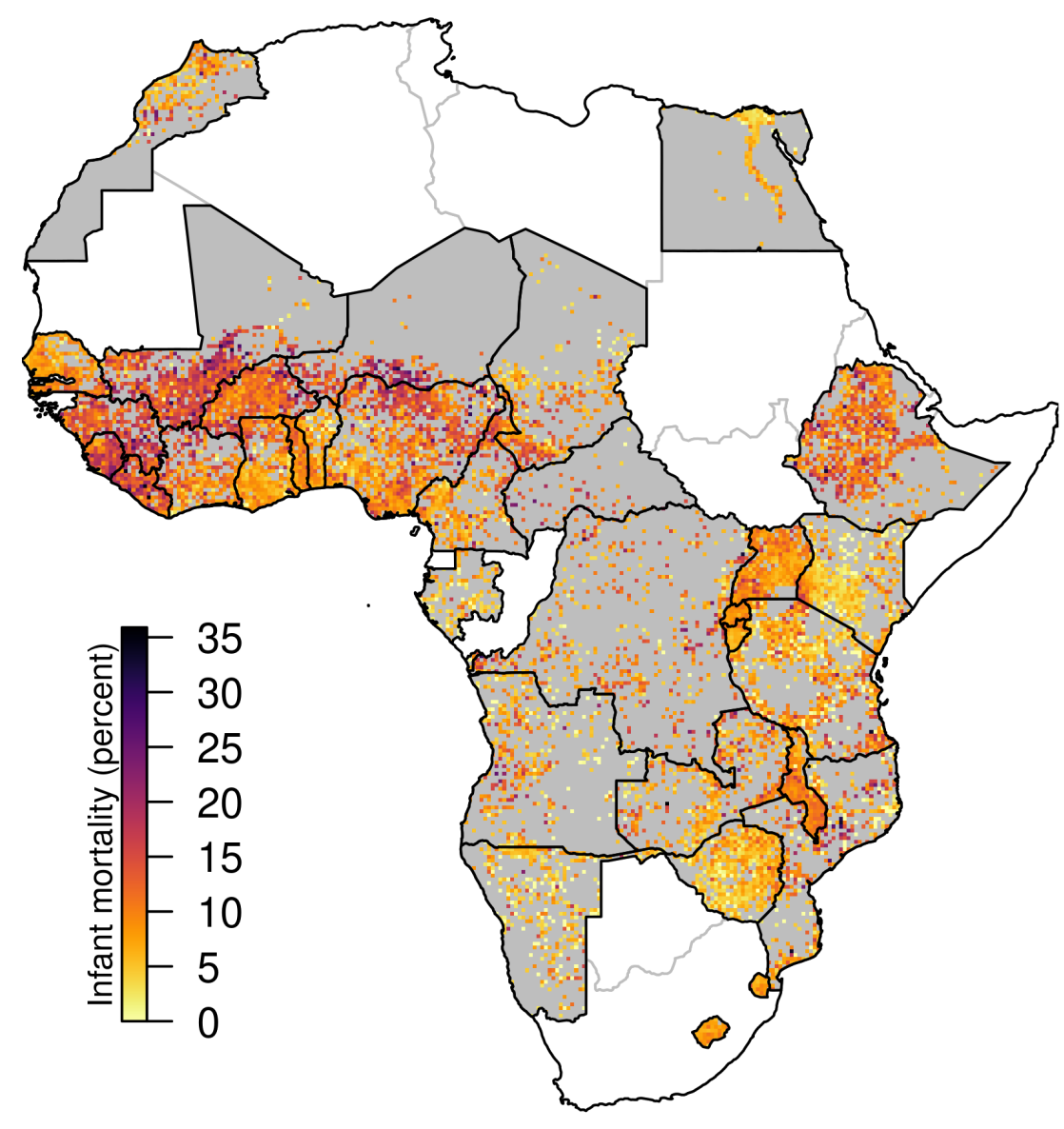

(b) Infant mortality in sample

Figure A13: Primary education and infant mortality in the DHS Data, aggregated to .25 raster cells. 


\section{E Robustness checks}

This section describes additional analyses that probe the robustness of the analysis of the effects of changes in the distance to national and regional capitals on local development. Figure A14 provides an overview over the various robustness checks. All additional models are described in detail below. Where Figure A14 captures the main insights from an additional analysis, I do not report detailed results as a table. However, the reader may note that all results will be made available as tables with the replication data.

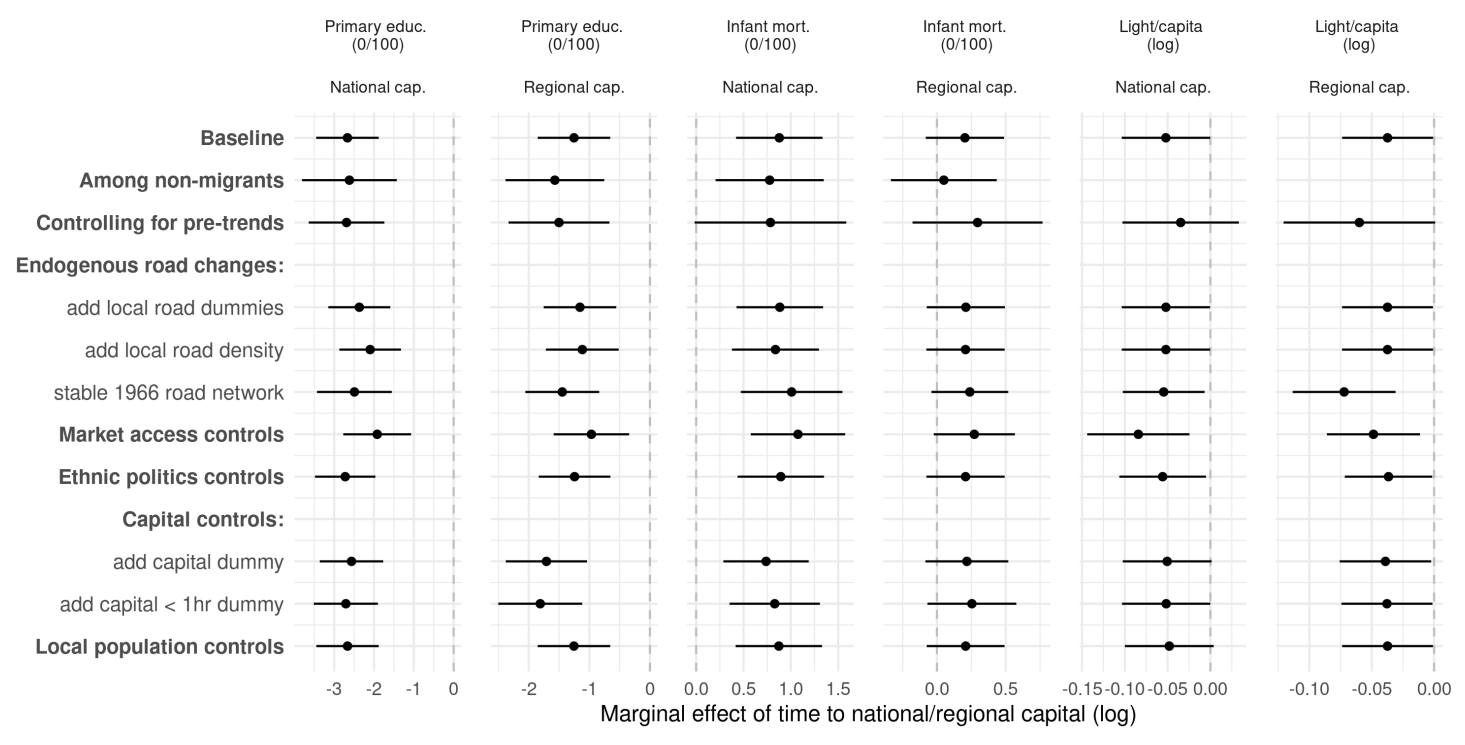

Figure A14: Panel analysis: Summary of robustness checks.

\section{E.1 Re-locations of national capitals vs. road-network development:}

One main concern of the analysis of changes in travel times to national capitals is that we observe only very few relocations of capitals that drive the results. In the sample of DHS respondents, capital re-locations have occurred in Côte d'Ivoire (Abidjan to Yamassoukro), Nigeria (Lagos to Abuja), and Tanzania (the de jure move from Dar es Salaam to Dodoma). The data on nightlights include the secessionist cases of Eritrea and South Sudan. In order to gauge whether the baseline estiamtes are due to these relocations and secessions or whether they are driven by changes in the road networks that link national capitals to their citizens, Table A6 presents the results of estimating the baseline panel specification on the split samples. For primary education rates we observe a larger effect in the sample of DHS respondents from countries with capital relocations, than from those without. However, also in the latter case the estimate is substantive and statistically significant, meaning that improved road connections to national capitals come with increases in local primary education rates. In the case of infant mortality rates, the results show them to be driven by capital relocations rather than road network improvements. Lastly and consistent with the baseline results, the results show only insignificant effects 
of either better road connections or new capitals on nightlight emissions. Note however, that the secessionist cases of Eritrea and South Sudan are each only observed one year pre-/post-treatment. We would hardly expect the new capitals to have such an immediate and sudden effect on nightlight emissions, in particular since both cases where riven by civil war before (and after, in the case of South Sudan) their secession.

Table A6: Changes in time to national/regional capital and local development: Cases where national capitals changed

\begin{tabular}{|c|c|c|c|c|c|c|}
\hline & \multicolumn{2}{|c|}{ Primary educ. $(0 / 100)$} & \multicolumn{2}{|c|}{ Infant mort. $(0 / 100)$} & \multicolumn{2}{|c|}{ Light/capita (log) } \\
\hline & $(1)$ & $(2)$ & (3) & $(4)$ & $(5)$ & (6) \\
\hline Time to nat. capital (log) & $\begin{array}{c}-1.807^{* * *} \\
(0.647)\end{array}$ & $\begin{array}{c}-3.159^{* * *} \\
(0.491)\end{array}$ & $\begin{array}{c}0.061 \\
(0.299)\end{array}$ & $\begin{array}{l}1.419^{* * *} \\
(0.309)\end{array}$ & $\begin{array}{c}-0.044 \\
(0.033)\end{array}$ & $\begin{array}{c}-0.054 \\
(0.036)\end{array}$ \\
\hline Time to reg. capital (log) & $\begin{array}{c}-1.483^{* * *} \\
(0.356)\end{array}$ & $\begin{array}{c}-0.743 \\
(0.595)\end{array}$ & $\begin{array}{c}0.164 \\
(0.153)\end{array}$ & $\begin{array}{c}0.906^{* *} \\
(0.453)\end{array}$ & $\begin{array}{c}-0.039^{*} \\
(0.020)\end{array}$ & $\begin{array}{r}-0.039^{*} \\
(0.023)\end{array}$ \\
\hline$\beta_{1}+\beta_{2}$ & $\begin{array}{c}-3.29^{* * *} \\
(0.669)\end{array}$ & $\begin{array}{c}-3.902^{* * *} \\
(0.754)\end{array}$ & $\begin{array}{c}0.225 \\
(0.302)\end{array}$ & $\begin{array}{l}2.325^{* * *} \\
(0.563)\end{array}$ & $\begin{array}{c}-0.083^{* *} \\
(0.033)\end{array}$ & $\begin{array}{c}-0.094^{* *} \\
(0.038)\end{array}$ \\
\hline Cap.-re-loc. cases: & drop & only & drop & only & drop & only \\
\hline Point FE: & yes & yes & yes & yes & yes & yes \\
\hline Country-year FE: & yes & yes & yes & yes & yes & yes \\
\hline Survey FE: & yes & yes & yes & yes & - & - \\
\hline Controls: & yes & yes & yes & yes & - & - \\
\hline Mean DV: & 70 & 72 & 9.5 & 10 & -6.5 & -6.8 \\
\hline Observations & $1,757,320$ & 334,416 & $2,478,438$ & 417,126 & $1,467,105$ & 39,908 \\
\hline Adjusted $\mathrm{R}^{2}$ & 0.454 & 0.438 & 0.051 & 0.049 & 0.838 & 0.395 \\
\hline
\end{tabular}

Notes: OLS linear models. Individuals are the units of the education and infant mortality analyses, Voronoi cells those of the nightlight analyses. Control variables for models with primary education as the dependent variable consist of responents' age and age squared, as well as a female dummy. Where infant mortality is the dependent variable, models include an infant's mother's age at birth and its square, the birthorder and its square, as well as a female and twin dummy. Standard errors clustered on the point and country-year levels. Significance codes: ${ }^{*} \mathrm{p}<0.1 ;{ }^{* *} \mathrm{p}<0.05 ; * * \mathrm{p}<0.01$

\section{E.2 Migration}

Over their lifetime, DHS respondents might have moved towards or away from changing regional (and national) capitals in a manner correlated with their level of education and wealth. Such migration patterns might bias the results. If that was the case, we should see differential effects of travel times among migrants and non-migrants. In particular, if migrants were driving the results, no effect of changes in the travel time towards capitals should be visible among non-migrants. Table A7 demonstrates that this is not the case. The effect of travel times on education rates is significantly larger for migrants than for non-migrants. In the case of infant mortality rates, the difference between the two sample is mostly insignificant, except for Model (4), which suggest that longer travel times to regional capitals have a more negative effect on infant mortality rates among migrantthan non-migrant mothers. Their absolute effect is however insignificantly different from zero in both cases (see also the lead-analysis below, Table A9). 
Table A7: Changes in time to national/regional capital and local development: Migrants and non-migrants

\begin{tabular}{|c|c|c|c|c|}
\hline & \multicolumn{2}{|c|}{ Primary educ. $(0 / 100)$} & \multicolumn{2}{|c|}{ Infant mort. $(0 / 100)$} \\
\hline & $(1)$ & $(2)$ & (3) & $(4)$ \\
\hline Time to nat. capital (log) & $\begin{array}{c}-2.618^{* * *} \\
(0.607)\end{array}$ & $\begin{array}{c}-2.540^{* * *} \\
(0.600)\end{array}$ & $\begin{array}{l}0.776^{* * *} \\
(0.291)\end{array}$ & $\begin{array}{l}0.607^{* *} \\
(0.284)\end{array}$ \\
\hline Time to reg. capital (log) & $\begin{array}{c}-1.569^{* * *} \\
(0.416)\end{array}$ & $\begin{array}{c}-1.511^{* * *} \\
(0.413)\end{array}$ & $\begin{array}{c}0.050 \\
(0.196)\end{array}$ & $\begin{array}{c}0.043 \\
(0.203)\end{array}$ \\
\hline Migrant & $\begin{array}{c}-4.031^{* * *} \\
(0.865)\end{array}$ & $\begin{array}{c}-13.190^{* * *} \\
(2.514)\end{array}$ & $\begin{array}{l}0.638^{* * *} \\
(0.240)\end{array}$ & $\begin{array}{l}1.861^{* * *} \\
(0.359)\end{array}$ \\
\hline Migrant $\times$ Time to nat. capital (log) & $\begin{array}{l}0.699^{* *} \\
(0.347)\end{array}$ & $\begin{array}{c}0.634^{*} \\
(0.341)\end{array}$ & $\begin{array}{c}0.220^{*} \\
(0.130)\end{array}$ & $\begin{array}{c}0.200 \\
(0.134)\end{array}$ \\
\hline Migrant $\times$ Time to reg. capital (log) & $\begin{array}{l}1.495^{* * *} \\
(0.285)\end{array}$ & $\begin{array}{l}1.304^{* * *} \\
(0.287)\end{array}$ & $\begin{array}{c}-0.151 \\
(0.151)\end{array}$ & $\begin{array}{c}-0.166 \\
(0.152)\end{array}$ \\
\hline Non-migrants: $\beta_{1}+\beta_{2}$ : & $\begin{array}{c}-4.187^{* * *} \\
(0.711)\end{array}$ & $\begin{array}{c}-4.051^{* * *} \\
(0.703)\end{array}$ & $\begin{array}{c}0.826^{* *} \\
(0.321) \\
\end{array}$ & $\begin{array}{c}0.65^{* *} \\
(0.317) \\
\end{array}$ \\
\hline Migrant $\times$ controls & no & yes & no & yes \\
\hline Point FE: & yes & yes & yes & yes \\
\hline Country-year FE: & yes & yes & yes & yes \\
\hline Survey FE: & yes & yes & yes & yes \\
\hline Controls: & yes & yes & yes & yes \\
\hline Mean DV: & 66 & 66 & 11 & 11 \\
\hline Observations & 650,045 & 650,045 & $1,532,319$ & $1,542,596$ \\
\hline Adjusted $\mathrm{R}^{2}$ & 0.483 & 0.483 & 0.052 & 0.034 \\
\hline
\end{tabular}

Notes: OLS linear models. Individuals are the units of the education and infant mortality analyses, Voronoi cells those of the nightlight analyses. Control variables for models with primary education as the dependent variable consist of responents' age and age squared, as well as a female dummy. Where infant mortality is the dependent variable, models include an infant's mother's age at birth and its square, the birthorder and its square, as well as a female and twin dummy. Standard errors clustered on the point and country-year levels. Significance codes: ${ }^{*} \mathrm{p}<0.1 ;{ }^{* *} \mathrm{p}<0.05 ;{ }^{* * *} \mathrm{p}<0.01$

\section{E.3 Testing for pre-trends and reverse causality}

As highlighted in the main text, one important threat to inference in the panel analysis is that the baseline estimates may be biased by differential pre-trends in local development that reversely cause the extension of state reach. I here present the full details of the empirical test that accounts for such trends. In particular, I re-estimate the baseline specification, adding measures of future travel times to capitals in $t+x$. These leads of the main treatments capture differential changes in local development that occur before changes in travel times affect localities. More specifically, for the analysis of local primary education rates, which are affected by state reach during age 6 to 11 of respondents, I estimate the effect of the average travel time to capitals during age 6-11, and add five separate controls for the travel times to capitals at age 12 to 16 . For infant mortality rates, which are affected only in the year of an infants' birth, I add the time to capitals at age 2 to 6 . Similarly, for local nightlight emissions, I add the respective variables for 


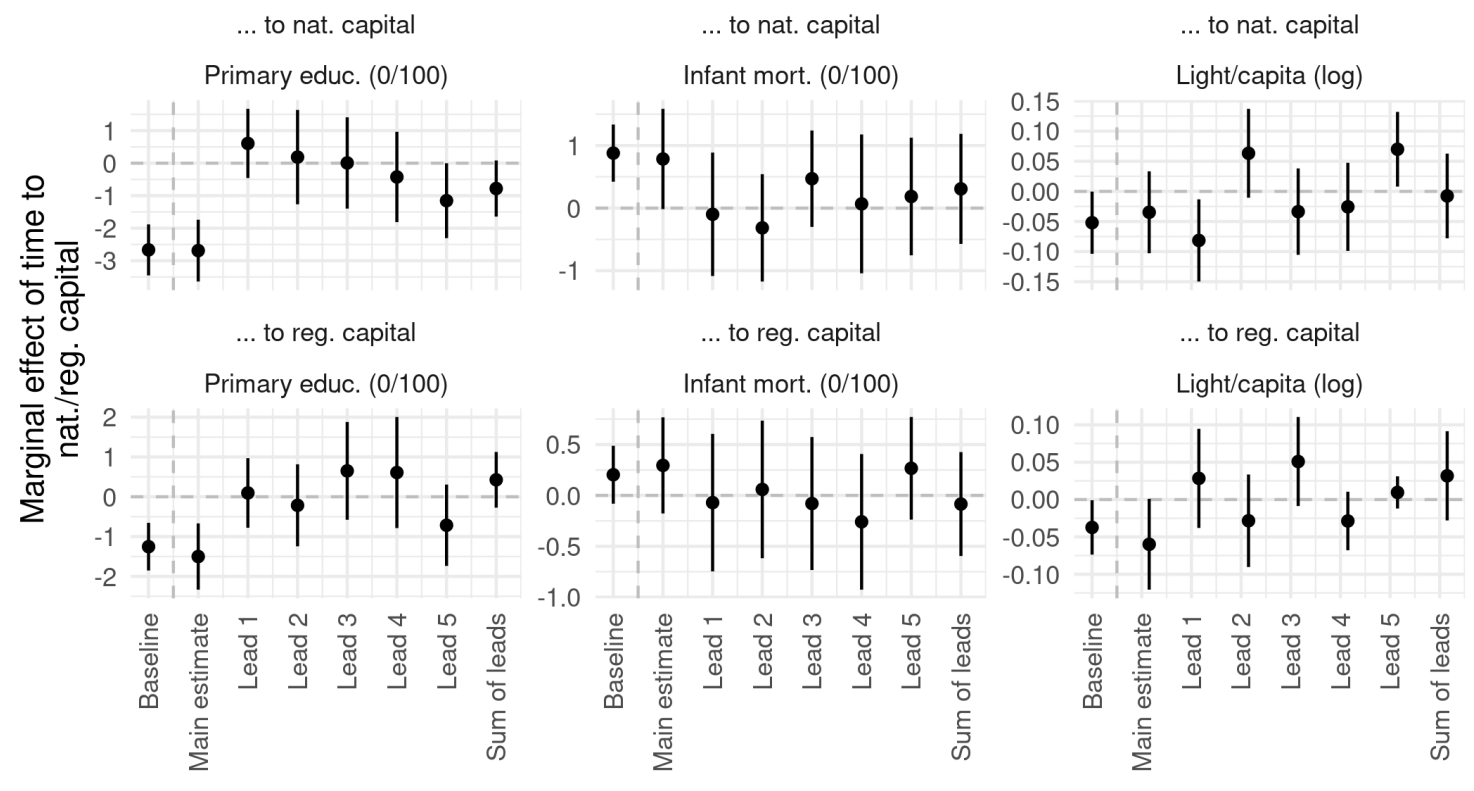

Figure A15: All leads, based on Table A8.

$t+1 \ldots 5$

$$
\begin{aligned}
& Y_{i, p, c, t, s}=\alpha_{p}+\lambda_{c, t}+\mu_{s}+\beta_{1} \text { time to nat. } \text { cap. }_{p, t}+\beta_{2} \text { time to reg. } \text { cap. }_{p, t}+\delta X_{i}+ \\
& \sum_{l=1}^{5} \gamma_{l} \text { time to nat. } \text { cap. }_{p, t+l}+\sum_{l=1}^{5} \zeta_{l} \text { time to reg. } \text { cap. }_{p, t+l}+\epsilon_{i, p, c, t} \text {, }
\end{aligned}
$$

Consistently significant estimates for gamma $_{l}$ and $z e t a_{l}$ or their sum that point in the same direction as the main result would reject the null-hypothesis of an absence of pretrends. Table A8 and Figure A15 show the results of these demanding ${ }^{26}$ specifications. The first thing to note is that the main estimates of the effects of travel times to capitals are only marginally and insignificantly different from those obtained in the baseline specification. This is a first sign that these are not affected by differential pre-trends. Second however, and as Table A8 shows, the sum of leads is negative and marginally significant in the estimation of the effect of travel times to national capitals on education rates. This suggests that education rates increase before capitals move closer to a location through roads or relocation. The leads in the infant mortality analysis are in sum close to zero and show few signs of divergent pre-trends. The leads in the nightlight analysis have very heterogeneous estimates, but are, for the most part statistically insignificant and in sum not different from zero. Both patterns suggest that the main estimate is not systematically affected by differential pre-trends.

One reason for the negative and marginally significant lead effect of travel times to national capitals on primary education rates consists in biased migration patterns by which

\footnotetext{
${ }^{26}$ The specifications are demanding because of the high correlations between the actual treatments and its leads.
} 
Table A8: Changes in time to national/regional capital and local development: Controlling for leads

\begin{tabular}{|c|c|c|c|}
\hline & $\begin{array}{c}\text { Primary educ. }(0 / 100) \\
\text { (1) }\end{array}$ & $\begin{array}{c}\text { Infant mort. }(0 / 100) \\
\text { (2) }\end{array}$ & $\begin{array}{c}\text { Light/capita (log) } \\
\text { (3) }\end{array}$ \\
\hline Time to nat. capital (log) & $\begin{array}{l}-2.690^{* * *} \\
(0.485)\end{array}$ & $\begin{array}{r}0.785^{*} \\
(0.409)\end{array}$ & $\begin{array}{c}-0.035 \\
(0.035)\end{array}$ \\
\hline Time to reg. capital (log) & $\begin{array}{l}-1.501^{* * *} \\
(0.425)\end{array}$ & $\begin{array}{l}0.295 \\
(0.241)\end{array}$ & $\begin{array}{r}-0.060^{*} \\
(0.031)\end{array}$ \\
\hline$\beta_{1}+\beta_{2}:$ & $\begin{array}{l}-4.191^{* * *} \\
(0.611)\end{array}$ & $\begin{array}{l}1.08^{* *} \\
(0.42)\end{array}$ & $\begin{array}{l}-0.095^{* * *} \\
(0.035)\end{array}$ \\
\hline Sum of leads (nat. cap.): & $\begin{array}{r}-0.78^{*} \\
(0.44)\end{array}$ & $\begin{array}{c}0.307 \\
(0.448)\end{array}$ & $\begin{array}{c}-0.008 \\
(0.036)\end{array}$ \\
\hline Sum of leads (reg cap.): & $\begin{array}{c}0.427 \\
(0.357) \\
\end{array}$ & $\begin{array}{r}-0.085 \\
(0.26) \\
\end{array}$ & $\begin{array}{c}0.032 \\
(0.03)\end{array}$ \\
\hline Time to cap $\cdot t+1, \ldots, t+5$ : & yes & yes & yes \\
\hline Point FE: & yes & yes & yes \\
\hline Country-year FE: & yes & yes & yes \\
\hline Survey FE: & yes & yes & - \\
\hline Controls: & yes & yes & - \\
\hline Mean DV: & 70 & 9.8 & -6.5 \\
\hline Observations & $2,083,138$ & $2,781,293$ & $1,369,922$ \\
\hline Adjusted $\mathrm{R}^{2}$ & 0.452 & 0.050 & 0.840 \\
\hline
\end{tabular}

Notes: OLS linear models. Individuals are the units of the education and infant mortality analyses, Voronoi cells those of the nightlight analyses. Control variables for models with primary education as the dependent variable consist of responents' age and age squared, as well as a female dummy. Where infant mortality is the dependent variable, models include an infant's mother's age at birth and its square, the birthorder and its square, as well as a female and twin dummy. Standard errors clustered on the point and country-year levels. Significance codes: ${ }^{*} \mathrm{p}<0.1{ }^{* *} \mathrm{p}<0.05 ;{ }^{* * *} \mathrm{p}<0.01$

individuals select in and out of treatment after having gone to school. These patterns can be picked up by the lead effects because I attribute travel times on the basis of the current location of DHS respondents. In order to test for this possibility, I re-estimate the respective specification, now interacting the treatment variables and their leads with a dummy for migrants. ${ }^{27}$ The respective variable is only available for the reduced sample of DHS respondents that have gone through the entire interview and is based on whether they have 'always' lived in their current place of residence. ${ }^{28}$

Reassuringly, the results in Table A9 show that the lead effects are only negative for the migrants in the sample, but positive for the non-migrants. Both sums of leads are statistically insignificant, presumable due to the smaller sample size. Furthermore, the main effect associated with travel times to national and regional capitals is much larger in the non-migrant sample than in the migrant sample, which is consistent with the fact that non-migrants' primary education is affected by local state reach to greater extent than that of migrants. The results for the respective analysis of the mortality of infants of non-migrant mothers mirror those described above, albeit with the caveat that the

\footnotetext{
${ }^{27}$ The baseline results for this migrant $\times$ travel times interaction without the leads is reported below in Subsection E.2.

${ }^{28}$ Note that the respective question does not allow to distinguish individuals who have moved within the same neighborhood from those who have migrated from one place to another. The migrant dummy therefore overestimates migration.
} 
children of migrant mothers are slightly - but only weakly significantly - more likely to survive close to capitals than those of non-migrant mothers.

Table A9: Changes in time to national/regional capital and local development: Controlling for leads, migrants and non-migrants

\begin{tabular}{|c|c|c|}
\hline & $\begin{array}{c}\text { Primary educ. }(0 / 100) \\
(1)\end{array}$ & $\begin{array}{c}\text { Infant mort. }(0 / 100) \\
(2)\end{array}$ \\
\hline Migrant & $\begin{array}{l}-3.798^{* * *} \\
(0.837)\end{array}$ & $\begin{array}{c}0.669 \\
(0.520)\end{array}$ \\
\hline Non-migrants: Time to nat. capital (log) & $\begin{array}{l}-1.544^{* *} \\
(0.612)\end{array}$ & $\begin{array}{c}0.189 \\
(0.356)\end{array}$ \\
\hline Non-migrants: Time to reg. capital (log) & $\begin{array}{l}-4.092^{* * *} \\
(0.880)\end{array}$ & $\begin{array}{l}0.627^{* *} \\
(0.244)\end{array}$ \\
\hline Migrants: Time to nat. capital (log) & $\begin{array}{r}-1.662^{*} \\
(0.900)\end{array}$ & $\begin{array}{c}-0.041 \\
(0.865)\end{array}$ \\
\hline Migrants: Time to reg. capital (log) & $\begin{array}{c}-0.152 \\
(0.871)\end{array}$ & $\begin{array}{c}-0.023 \\
(0.548)\end{array}$ \\
\hline Non-migrants: $\beta_{1}+\beta_{2}$ : & $\begin{array}{l}-5.341^{* * *} \\
(1.012)\end{array}$ & $\begin{array}{c}0.858 \\
(0.564)\end{array}$ \\
\hline \multicolumn{3}{|l|}{ Non-migrant leads: } \\
\hline Sum of leads (nat. cap.): & $\begin{array}{l}0.493 \\
(0.707)\end{array}$ & $\begin{array}{c}0.345 \\
(0.568)\end{array}$ \\
\hline Sum of leads (reg. cap.): & $\begin{array}{c}-0.294 \\
(0.525)\end{array}$ & $\begin{array}{r}-0.146 \\
(0.381)\end{array}$ \\
\hline \multicolumn{3}{|l|}{ Migrant leads: } \\
\hline Sum of leads (nat. cap.): & $\begin{array}{r}-0.965 \\
(0.763)\end{array}$ & $\begin{array}{c}1.315 \\
(0.888)\end{array}$ \\
\hline Sum of leads (reg. cap.): & $\begin{array}{c}-0.087 \\
(0.818) \\
\end{array}$ & $\begin{array}{c}-0.131 \\
(0.552) \\
\end{array}$ \\
\hline Time to cap $\cdot t+1, \ldots, t+5$ : & yes & yes \\
\hline Point FE: & yes & yes \\
\hline Country-year FE: & yes & yes \\
\hline Survey FE: & yes & yes \\
\hline Controls: & yes & yes \\
\hline Mean DV: & 66 & 11 \\
\hline Observations & 648,126 & $1,505,657$ \\
\hline Adjusted $\mathrm{R}^{2}$ & 0.483 & 0.052 \\
\hline
\end{tabular}

Notes: OLS linear models. Individuals are the units of the education and infant mortality analyses, Voronoi cells those of the nightlight analyses. Control variables for models with primary education as the dependent variable consist of responents' age and age squared, as well as a female dummy. Where infant mortality is the dependent variable, models include an infant's mother's age at birth and its square, the birthorder and its square, as well as a female and twin dummy. Standard errors clustered on the point and country-year levels. Significance codes: ${ }^{*} p<0.1 ;{ }^{* *} p<0.05 ;{ }^{* * *} p<0.01$

\section{E.4 Potentially endogenous road building}

The main results might also be driven by roads that are built at the local level around specific towns and villages. Because such road building inherently lowers the distance to all capitals, it might lead to spurious results if it was caused by increasing levels of development in these areas. To exclude such omitted variable bias, I employ two strategies. First, I control for the mileage of roads in the geographic neighborhood of respondents 


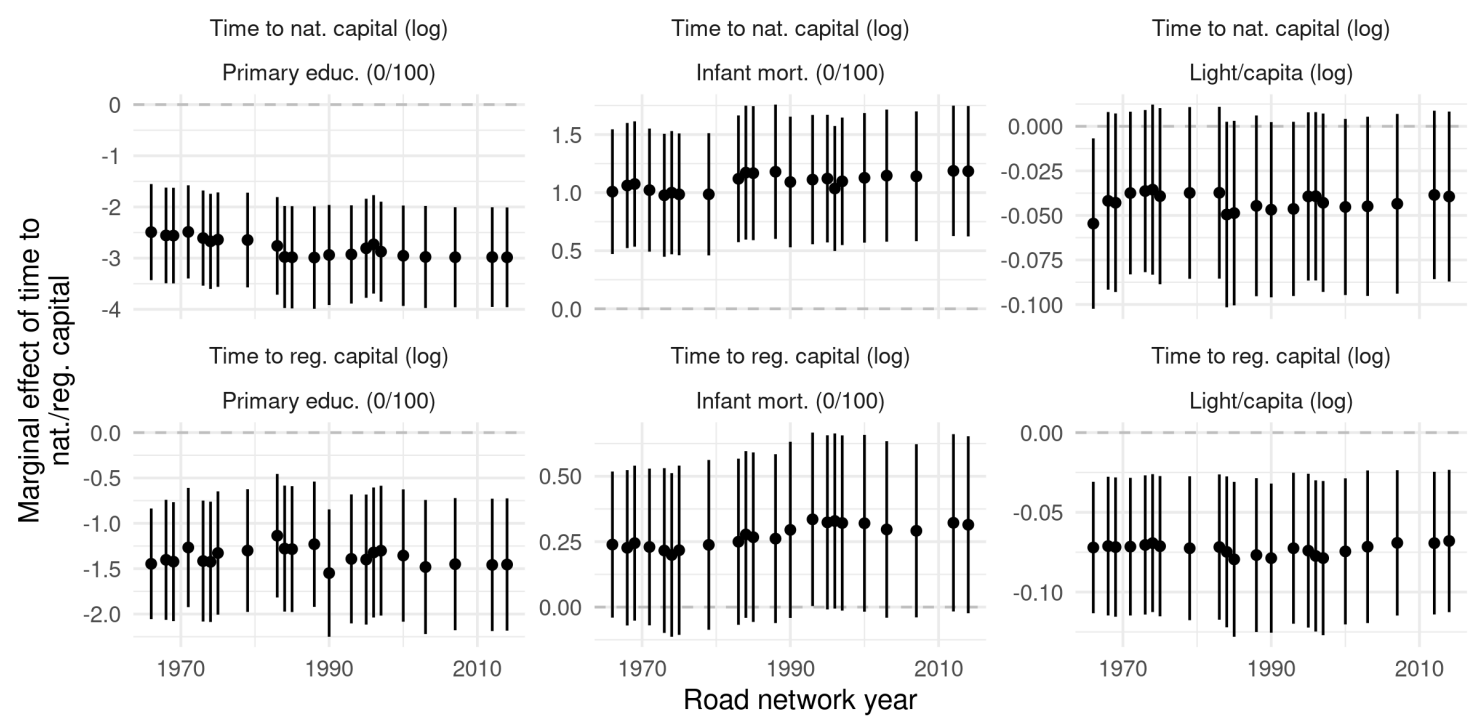

Figure A16: Estimating the baseline models with constant road networks from varying years

$(20 \mathrm{~km}) /$ in a Voronoi cell (see Figure A14). This is similar to the strategy of Donaldson and Hornbeck (2016) in that the variation left stems from changes in the road network outside a particular point's neighborhood. The second and more stringent test is to reestimate all models with non-time variant road networks. In such a setting, all variation within points stems solely from changes in the administrative design of a country - that is the location of boundaries and capitals. I do so with each Michelin network that I observe. The results, plotted in Figure A16, are insensitive towards these changes - it appears that the magnitude of baseline results are unaffected by purging the model of temporal variance induced through changes in road networks. If at all, the absolute size of the estimates slightly increases.

\section{E.5 Omitted variables and spurious correlations}

Controlling for spuriously correlated economic market access Travel times to regional and national capitals might not only proxy for transaction costs between governments and citizens, but more broadly transaction costs between the participants of economic markets. Variation in economic market access might lead to spurious results, since it results in higher levels of economic activity and development (e.g. Donaldson 2018; Donaldson and Hornbeck 2016; Eaton and Kortum 2002; Jedwab and Moradi 2016; Jedwab and Storeygard 2018). I thus follow the economic literature on the effect of market access on economic growth and calculate, for each year, the road-network based access to national and international markets. Following Donaldson (2018) and Eaton and Kortum (2002), I define the measure as: 


$$
M A_{p, t}=\sum_{m=1}^{M} c_{p, m, t}^{-\theta} * P_{m, t},
$$

where the market access of point $p$ in year $t$ is the sum of the market potential $P$ of a market $m$ in year $t$ multiplied by the travel time between $p$ and $m$ calculated on the road network and discounted by a trade elasticity $\theta$. Because Donaldson (2018) and Eaton and Kortum (2002) estimate different trade elasticity measures ( $\theta=8.28$ and 3.2 respectively), I construct the market access measure for both parameters. Because the effects of access to national and international markets might differ, I calculate $M A$ separately for markets inside and outside of $p^{\prime}$ s country. I define markets as the 1530 biggest cities and towns in Africa. These are all cities that ever reached more then 50'000 inhabitants since $1950^{29}$. Each city's market potential $P$ is approximated by its population as measured in each decade. Controlling for the four resulting variables in Table A10 indicates does not affect the magnitude of the effects associated with the measures of state reach. This indicates that a low distance towards capital cities increases local development above and beyond the effect of the economic markets they harbor. The effect of market access on education rates is slightly positive, once we take the sum of the respective coefficients. They have a mixed effect of infant mortality and nightlight emissions.

Controlling for ethnic politics and war: Ethnic politics are an important driver of both, development and state reach. Research on administrative unit reforms has found that they can reward government allies (Green 2010; Hassan 2016; Gottlieb et al. 2019) or harm opponents (Resnick 2017), strategies which may well be used in processes of ethnic accommodation or exclusion. At the same time, ethnic and regional favoritism of governments has been found to affect investments into road infrastructure (Burgess et al. 2015) and local development in general (Franck and Rainer 2012; Hodler and Raschky 2014). To capture such dynamics, I draw on the most comprehensive and geocoded data on ethnic power dynamics in Africa since independence, the Ethnic Power Relations data set (Vogt et al. 2015). ${ }^{30}$ I use the geodata of ethnic groups to map respondents and Voronoi cells to the database's coding of ethnic inclusion and exclusion as well as the occurrence and history of ethnic civil wars. Table A11 shows the results from the baseline analysis with the resulting variables as additional controls. The additional controls do not affect the results. While in particular the time since the last ethnic civil war positively affects education rates, ethnic inclusion has a positive effect on infant survival rates and nightlight emissions.

\footnotetext{
${ }^{29}$ Data comes from Africapolis.org.

${ }^{30}$ All data can be freely downloaded from growup . ethz . ch.
} 
Table A10: Changes in time to national/regional capital and local development: Controlling for market access

\begin{tabular}{|c|c|c|c|}
\hline & \multicolumn{3}{|c|}{ Primary educ. $(0 / 100)$} \\
\hline & $(1)$ & (2) & (3) \\
\hline Time to nat. capital (log) & $\begin{array}{c}-1.919^{* * *} \\
(0.434)\end{array}$ & $\begin{array}{l}1.076^{* * *} \\
(0.254)\end{array}$ & $\begin{array}{c}-0.084^{* * *} \\
(0.030)\end{array}$ \\
\hline Time to reg. capital (log) & $\begin{array}{c}-0.966^{* * *} \\
(0.318)\end{array}$ & $\begin{array}{c}0.272^{*} \\
(0.151)\end{array}$ & $\begin{array}{c}-0.049^{* *} \\
(0.019)\end{array}$ \\
\hline MA, internat. $(\log ; \theta=3.8)$ & $\begin{array}{l}2.178^{* * *} \\
(0.482)\end{array}$ & $\begin{array}{c}0.378 \\
(0.248)\end{array}$ & $\begin{array}{c}-0.146^{* * *} \\
(0.018)\end{array}$ \\
\hline MA, nat. $(\log ; \theta=3.8)$ & $\begin{array}{c}-0.804^{* * *} \\
(0.167)\end{array}$ & $\begin{array}{c}-0.025 \\
(0.081)\end{array}$ & $\begin{array}{l}0.082^{* * *} \\
(0.007)\end{array}$ \\
\hline MA, internat. $(\log ; \theta=8.28)$ & $\begin{array}{c}0.478 \\
(0.323)\end{array}$ & $\begin{array}{c}0.250 \\
(0.182)\end{array}$ & $\begin{array}{c}-0.009 \\
(0.011)\end{array}$ \\
\hline MA, nat. $(\log ; \theta=8.28)$ & $\begin{array}{c}-0.149 \\
(0.115)\end{array}$ & $\begin{array}{c}-0.098 \\
(0.074)\end{array}$ & $\begin{array}{l}0.034^{* * *} \\
(0.006)\end{array}$ \\
\hline$\beta_{1}+\beta_{2}:$ & $\begin{array}{c}-2.886^{* * *} \\
(0.527) \\
\end{array}$ & $\begin{array}{l}1.347^{* * *} \\
(0.297)\end{array}$ & $\begin{array}{c}-0.133^{* * *} \\
(0.034) \\
\end{array}$ \\
\hline Point FE: & yes & yes & yes \\
\hline Country-year FE: & yes & yes & yes \\
\hline Survey FE: & yes & yes & - \\
\hline Controls: & yes & yes & - \\
\hline Mean DV: & 70 & 9.6 & -6.5 \\
\hline Observations & $2,088,301$ & $2,895,505$ & $1,507,013$ \\
\hline Adjusted $\mathrm{R}^{2}$ & 0.452 & 0.051 & 0.836 \\
\hline
\end{tabular}

Notes: OLS linear models. Individuals are the units of the education and infant mortality analyses, Voronoi cells those of the nightlight analyses. Control variables for models with primary education as the dependent variable consist of responents' age and age squared, as well as a female dummy. Where infant mortality is the dependent variable, models include an infant's mother's age at birth and its square, the birthorder and its square, as well as a female and twin dummy. Standard errors clustered on the point and country-year levels. Significance codes: ${ }^{*} \mathrm{p}<0.1 ;{ }^{* *} \mathrm{p}<0.05 ;{ }^{* * *} \mathrm{p}<0.01$ 
Table A11: Changes in time to national/regional capital and local development: Controlling for ethnic representation and civil war

\begin{tabular}{|c|c|c|c|}
\hline & \multicolumn{3}{|c|}{ Primary educ. $(0 / 100)$} \\
\hline & $(1)$ & (2) & (3) \\
\hline Time to nat. capital (log) & $\begin{array}{c}-2.723^{* * *} \\
(0.387)\end{array}$ & $\begin{array}{l}0.894^{* * *} \\
(0.233)\end{array}$ & $\begin{array}{c}-0.056^{* *} \\
(0.026)\end{array}$ \\
\hline Time to reg. capital (log) & $\begin{array}{c}-1.244^{* * *} \\
(0.301)\end{array}$ & $\begin{array}{c}0.208 \\
(0.145)\end{array}$ & $\begin{array}{c}-0.037^{* *} \\
(0.018)\end{array}$ \\
\hline Ethnic inclusion $(0 / 1)$ & $\begin{array}{c}0.978 \\
(0.638)\end{array}$ & $\begin{array}{c}-0.573^{* *} \\
(0.227)\end{array}$ & $\begin{array}{l}0.084^{* * *} \\
(0.024)\end{array}$ \\
\hline Ethnic exclusion $(0 / 1)$ & $\begin{array}{c}1.138^{*} \\
(0.639)\end{array}$ & $\begin{array}{r}-0.384^{*} \\
(0.216)\end{array}$ & $\begin{array}{c}0.036^{*} \\
(0.020)\end{array}$ \\
\hline Ethnic civil war $(0 / 1)$ & $\begin{array}{c}0.514 \\
(0.688)\end{array}$ & $\begin{array}{c}-0.123 \\
(0.212)\end{array}$ & $\begin{array}{l}0.037^{* * *} \\
(0.010)\end{array}$ \\
\hline Eth. war since indep. $(0 / 1)$ & $\begin{array}{c}0.777 \\
(0.819)\end{array}$ & $\begin{array}{c}-0.117 \\
(0.298)\end{array}$ & $\begin{array}{c}-0.048^{* * *} \\
(0.017)\end{array}$ \\
\hline Time since eth. war & $\begin{array}{l}0.405^{* * *} \\
(0.124)\end{array}$ & $\begin{array}{c}-0.019 \\
(0.035)\end{array}$ & $\begin{array}{c}-0.001 \\
(0.001)\end{array}$ \\
\hline Time since eth. war ${ }^{2}$ & $\begin{array}{c}-0.015^{* * *} \\
(0.003)\end{array}$ & $\begin{array}{c}0.001 \\
(0.001)\end{array}$ & $\begin{array}{c}0.00000 \\
(0.00002)\end{array}$ \\
\hline$\beta_{1}+\beta_{2}:$ & $\begin{array}{c}-3.967^{* * *} \\
(0.456) \\
\end{array}$ & $\begin{array}{l}1.102^{\text {*** }} \\
(0.262) \\
\end{array}$ & $\begin{array}{c}-0.092^{* * *} \\
(0.028) \\
\end{array}$ \\
\hline Point FE: & yes & yes & yes \\
\hline Country-year FE: & yes & yes & yes \\
\hline Survey FE: & yes & yes & - \\
\hline Controls: & yes & yes & - \\
\hline Mean DV: & 70 & 9.6 & -6.5 \\
\hline Observations & 2,091,736 & $2,882,233$ & $1,507,013$ \\
\hline Adjusted $\mathrm{R}^{2}$ & 0.452 & 0.050 & 0.836 \\
\hline
\end{tabular}

Notes: OLS linear models. Individuals are the units of the education and infant mortality analyses, Voronoi cells those of the nightlight analyses. Control variables for models with primary education as the dependent variable consist of responents' age and age squared, as well as a female dummy. Where infant mortality is the dependent variable, models include an infant's mother's age at birth and its square, the birthorder and its square, as well as a female and twin dummy. Standard errors clustered on the point and country-year levels. Significance codes: ${ }^{*} \mathrm{p}<0.1 ;{ }^{* *} \mathrm{p}<0.05 ;{ }^{* * *} \mathrm{p}<0.01$ 
Controlling for capitals: Another potential danger is that as some cities may become, for a variety of reasons, richer with time, and then benefit from a political upgrade and get their own administrative unit. In such cases, changes in state reach in that city would be endogenous to local development. In an additional robustness check I therefore include dummies for whether an interview-location was (1) in and (2) closer than 1 hour to a regional and national capital in time $t$. For the Voronoi units, I create analagous measures when they either contain a capital or have an average distance to a capital of below 1 hour. The results in Table A12 highlight that changes in distances towards capitals in locations which are not capitals themselves drive the baseline patterns. Above and beyond the effect associated with a reduction in travel times, becoming a regional capital is associated with lower education rates, and more mixed patterns in the other outcomes. Relocations of national capitals are associated with reductions of infant mortality rates in the new capitals.

Table A12: Changes in time to national/regional capital and local development: Controlling for capitals

\begin{tabular}{|c|c|c|c|c|c|c|}
\hline & \multicolumn{2}{|c|}{ Primary educ. $(0 / 100)$} & \multicolumn{2}{|c|}{ Infant mort. $(0 / 100)$} & \multicolumn{2}{|c|}{ Light/capita (log) } \\
\hline & $(1)$ & (2) & (3) & $(4)$ & $(5)$ & $(6)$ \\
\hline Time to nat. capital (log) & $\begin{array}{c}-2.565^{* * *} \\
(0.406)\end{array}$ & $\begin{array}{c}-2.707^{* * *} \\
(0.411)\end{array}$ & $\begin{array}{l}0.739^{* * *} \\
(0.230)\end{array}$ & $\begin{array}{l}0.830^{* * *} \\
(0.243)\end{array}$ & $\begin{array}{c}-0.051^{*} \\
(0.026)\end{array}$ & $\begin{array}{r}-0.052^{*} \\
(0.026)\end{array}$ \\
\hline Time to reg. capital (log) & $\begin{array}{c}-1.708^{* * *} \\
(0.342)\end{array}$ & $\begin{array}{c}-1.810^{* * *} \\
(0.353)\end{array}$ & $\begin{array}{c}0.218 \\
(0.154)\end{array}$ & $\begin{array}{c}0.254 \\
(0.165)\end{array}$ & $\begin{array}{c}-0.039^{* *} \\
(0.019)\end{array}$ & $\begin{array}{c}-0.038^{* *} \\
(0.019)\end{array}$ \\
\hline National capital $(0 / 1)$ & $\begin{array}{c}-0.417 \\
(3.252)\end{array}$ & & $\begin{array}{c}-5.869^{* * *} \\
(2.244)\end{array}$ & & $\begin{array}{c}0.200 \\
(0.265)\end{array}$ & \\
\hline Regional capital $(0 / 1)$ & $\begin{array}{c}-3.092^{* * *} \\
(1.082)\end{array}$ & & $\begin{array}{c}0.036 \\
(0.426)\end{array}$ & & $\begin{array}{c}-0.049 \\
(0.051)\end{array}$ & \\
\hline Time to nat. cap. $<1 \mathrm{hr}$ & & $\begin{array}{c}-0.574 \\
(0.598)\end{array}$ & & $\begin{array}{c}-0.241 \\
(0.388)\end{array}$ & & $\begin{array}{l}0.099^{* *} \\
(0.043)\end{array}$ \\
\hline Time to reg. cap $<1 \mathrm{hr}$ & & $\begin{array}{c}-1.285^{* * *} \\
(0.370)\end{array}$ & & $\begin{array}{c}0.117 \\
(0.170)\end{array}$ & & $\begin{array}{c}-0.027 \\
(0.033)\end{array}$ \\
\hline$\beta_{1}+\beta_{2}:$ & $\begin{array}{c}-4.274^{* * *} \\
(0.479)\end{array}$ & $\begin{array}{c}-4.517^{* * *} \\
(0.492)\end{array}$ & $\begin{array}{l}0.956^{* * *} \\
(0.263) \\
\end{array}$ & $\begin{array}{l}1.084^{* * *} \\
(0.278)\end{array}$ & $\begin{array}{c}-0.09^{* * *} \\
(0.028) \\
\end{array}$ & $\begin{array}{c}-0.089^{* * *} \\
(0.028)\end{array}$ \\
\hline Point FE: & yes & yes & yes & yes & yes & yes \\
\hline Country-year FE: & yes & yes & yes & yes & yes & yes \\
\hline Survey FE: & yes & yes & yes & yes & - & - \\
\hline Controls: & yes & yes & yes & yes & - & - \\
\hline Mean DV: & 70 & 70 & 9.6 & 9.6 & -6.5 & -6.5 \\
\hline Observations & $2,091,724$ & $2,091,736$ & $2,895,545$ & $2,895,564$ & $1,507,013$ & $1,507,013$ \\
\hline Adjusted $\mathrm{R}^{2}$ & 0.452 & 0.452 & 0.051 & 0.051 & 0.836 & 0.836 \\
\hline
\end{tabular}

Notes: OLS linear models. Individuals are the units of the education and infant mortality analyses, Voronoi cells those of the nightlight analyses. Control variables for models with primary education as the dependent variable consist of responents' age and age squared, as well as a female dummy. Where infant mortality is the dependent variable, models include an infant's mother's age at birth and its square, the birthorder and its square, as well as a female and twin dummy. Standard errors clustered on the point and country-year levels. Significance codes: ${ }^{*} \mathrm{p}<0.1 ;{ }^{* *} \mathrm{p}<0.05 ;{ }^{* * *} \mathrm{p}<0.01$ 


\section{E.6 Varying education- and health-related outcomes:}

Lastly, two sets of additional analyses gauge whether the results are applicable to alternative education and health care outcomes. First, Table A13 shows very similar effects of the travel time to regional and national capitals on (1) whether a respondent has spent any time in school, (2) on her years of schooling - logged and linear, and (3) on a simple secondary education dummy. The main deviation from the baseline model is that the distance to the national capital does not seem to impact secondary education levels. With regard to infant mortality, Table A14 indicates that increased infant mortality in regions of low state reach can indeed be related to a lower availability of professional prenatal assistants. Similarly, changes in travel times to national capitals come with an increased chance that a child is born in a public clinic and positively relate to the receipt of professional assistance during delivery. Conversely, if children are born under low levels of state reach from the national capital, assistance is given more often in traditional manner. Consistent with the earlier results, the distance to regional capitals does not have any significant effect on the receipt of professional prenatal or birth assistance. Regarding local development measured through nightlight emissions, Table A15 shows that the choice of outcomes - whether nightlights per capita (log), absolute nightlights $(\log )$, or a dummy for whether a Voronoi cell exhibits any nightlight emissions does not produce different conclusions. In all three cases, changes in travel times to capitals are in sum associated with more nightlights. The estimated effect of changes in travel times towards national capitals are statistically significant, with the exception of their effect on the logged amount of absolute nightlight emissions.

Table A13: Changes in time to national/regional capital and various education outcomes

\begin{tabular}{|c|c|c|c|c|}
\hline & $\begin{array}{l}\text { Any educ. }(0 / 100) \\
\text { (1) }\end{array}$ & $\begin{array}{l}\text { Educ. years (linear) } \\
\text { (2) }\end{array}$ & $\begin{array}{l}\text { Educ. years }(\log ) \\
\text { (3) }\end{array}$ & $\begin{array}{c}\text { Sec. educ. }(0 / 100) \\
\text { (4) }\end{array}$ \\
\hline Time to nat. capital (log) & $\begin{array}{l}-2.667^{* * *} \\
(0.401)\end{array}$ & $\begin{array}{l}-0.231^{* * *} \\
(0.046)\end{array}$ & $\begin{array}{l}-0.055^{* * *} \\
(0.009)\end{array}$ & $\begin{array}{c}-0.023 \\
(0.423)\end{array}$ \\
\hline Time to reg. capital (log) & $\begin{array}{l}-1.229^{* * *} \\
(0.309)\end{array}$ & $\begin{array}{c}-0.082^{* *} \\
(0.032)\end{array}$ & $\begin{array}{l}-0.026^{* * *} \\
(0.007)\end{array}$ & $\begin{array}{l}-0.927^{* * *} \\
(0.314)\end{array}$ \\
\hline$\beta_{1}+\beta_{2}:$ & $\begin{array}{l}-3.897^{* * *} \\
(0.467)\end{array}$ & $\begin{array}{l}-0.312^{* * *} \\
(0.051)\end{array}$ & $\begin{array}{l}-0.081^{* * *} \\
(0.01)\end{array}$ & $\begin{array}{c}-0.95^{*} \\
(0.485)\end{array}$ \\
\hline Point FE: & yes & yes & yes & yes \\
\hline Country-year FE: & yes & yes & yes & yes \\
\hline Survey FE: & yes & yes & yes & yes \\
\hline Controls: & yes & yes & yes & yes \\
\hline Mean DV: & 70 & 5.5 & 1.5 & 35 \\
\hline Observations & $2,088,917$ & $2,088,917$ & $2,088,917$ & $1,787,251$ \\
\hline Adjusted $\mathrm{R}^{2}$ & 0.450 & 0.462 & 0.489 & 0.356 \\
\hline
\end{tabular}

Notes: OLS linear models. Control variables include respondents' age and age squared, as well as a female dummy. Standard errors clustered on the point and country-year levels. Significance codes: ${ }^{*} \mathrm{p}<0.1 ;{ }^{* *} \mathrm{p}<0.05 ;{ }^{* * *} \mathrm{p}<0.01$ 
Table A14: Changes in time to national/regional capital and quality of prenatal care and birth assistance (in percent)

\begin{tabular}{|c|c|c|c|c|}
\hline & $\begin{array}{c}\text { Prof. prenatal care } \\
(1)\end{array}$ & $\begin{array}{l}\text { Birth in public inst. } \\
\text { (2) }\end{array}$ & $\begin{array}{l}\text { Prof. birth assist. } \\
\text { (3) }\end{array}$ & $\begin{array}{c}\text { Trad. birth assist. } \\
\text { (4) }\end{array}$ \\
\hline Time to nat. capital (log) & $\begin{array}{c}-9.465^{* * *} \\
(2.379)\end{array}$ & $\begin{array}{c}-2.476 \\
(1.641)\end{array}$ & $\begin{array}{c}-7.353^{* * *} \\
(1.938)\end{array}$ & $\begin{array}{c}3.765^{* *} \\
(1.536)\end{array}$ \\
\hline Time to reg. capital (log) & $\begin{array}{c}-0.139 \\
(1.018)\end{array}$ & $\begin{array}{c}-0.316 \\
(0.997)\end{array}$ & $\begin{array}{c}0.191 \\
(0.937)\end{array}$ & $\begin{array}{l}1.026 \\
(0.702)\end{array}$ \\
\hline$\overline{\beta_{1}+\beta_{2}:}$ & $\begin{array}{c}-9.604^{* * *} \\
(2.554)\end{array}$ & $\begin{array}{c}-2.792 \\
(1.737) \\
\end{array}$ & $\begin{array}{l}-7.162^{* * *} \\
(2.08)\end{array}$ & $\begin{array}{l}4.791^{* * *} \\
(1.593)\end{array}$ \\
\hline Point FE: & yes & yes & yes & yes \\
\hline Country-year FE: & yes & yes & yes & yes \\
\hline Survey FE: & yes & yes & yes & yes \\
\hline Controls: & yes & yes & yes & yes \\
\hline Mean DV: & 81 & 38 & 54 & 19 \\
\hline Observations & 458,841 & 643,916 & 642,668 & 637,780 \\
\hline Adjusted $\mathrm{R}^{2}$ & 0.467 & 0.409 & 0.440 & 0.319 \\
\hline
\end{tabular}

Notes: OLS linear models. Control variables include an infant's mother's age and age squared, the birthorder and its square, as well as a female and twin dummy. Standard errors clustered on the point and country-year levels. Significance codes: ${ }^{*} \mathrm{p}<0.1 ;{ }^{* *} \mathrm{p}<0.05 ;{ }^{* * *} \mathrm{p}<0.01$

Table A15: Changes in time to national/regional capital and various nightlight measures

\begin{tabular}{|c|c|c|c|}
\hline & $\begin{array}{c}\text { Light/capita (log) } \\
\text { (1) }\end{array}$ & $\begin{array}{l}\text { Light }(\log ) \\
\text { (2) }\end{array}$ & $\begin{array}{c}\text { Any Light }(0 / 100) \\
\text { (3) }\end{array}$ \\
\hline Time to nat. capital (log) & $\begin{array}{c}-0.052^{* *} \\
(0.026)\end{array}$ & $\begin{array}{c}-0.114 \\
(0.072)\end{array}$ & $\begin{array}{c}-1.224^{* *} \\
(0.588)\end{array}$ \\
\hline Time to reg. capital (log) & $\begin{array}{c}-0.037^{* *} \\
(0.019)\end{array}$ & $\begin{array}{r}-0.112^{*} \\
(0.062)\end{array}$ & $\begin{array}{r}-0.861^{*} \\
(0.500)\end{array}$ \\
\hline$\beta_{1}+\beta_{2}:$ & $\begin{array}{l}-0.089^{* * *} \\
(0.028)\end{array}$ & $\begin{array}{l}-0.225^{* * *} \\
(0.07)\end{array}$ & $\begin{array}{l}-2.085^{* * *} \\
(0.57)\end{array}$ \\
\hline Unit FE: & yes & yes & yes \\
\hline Country-year FE: & yes & yes & yes \\
\hline Controls: & _- & _- & _- \\
\hline Mean DV: & -6.5 & -5.4 & 12 \\
\hline Observations & $1,507,013$ & $1,507,013$ & $1,507,013$ \\
\hline Adjusted $\mathrm{R}^{2}$ & 0.836 & 0.838 & 0.784 \\
\hline
\end{tabular}

\section{E.7 Additional robustness checks:}

Country-weights: Because the DHS has not regularly sampled all African countries, the weights each country receives in the baseline specifications vary considerably. If the effects of state capacity on development vary systematically with the number and size of survey the DHS by countries, the results would be biased towards the most-sampled set of countries. Table A16 addresses this caveat by weighting each observation by the inverse of the number of observations from its country (Models 1 and 3) and from the re- 
spective cohort in the same country (Models 2 and 4). The latter serves to prevent that the biggest cohorts drive the results at the expense of dynamics in smaller cohorts observed in the data. ${ }^{31}$ Though coefficients slightly change, the results remain generally consistent with those reported at the baseline. Lastly, Model 5 addresses the potential problem that until now I have treated all Voronoi cells in the same manner, thus giving equal weight to areas with many and few inhabitants. Weighting the Voronoi units by their population roughly doubles the estimated effect of the travel time to regional capitals on nightlight emissions. This is reassuring, since it shows that the results above are not driven by areas with very low population densities that are prone to produce outliers in the per-capita nightlight measure. As in some previous results, the effect of the travel time to national capitals, is statistically insignificant.

Table A16: Changes in time to national/regional capital and local development: Alternative weights

\begin{tabular}{|c|c|c|c|c|c|}
\hline & \multicolumn{2}{|c|}{ Primary educ. $(0 / 100)$} & \multicolumn{2}{|c|}{ Infant mort. $(0 / 100)$} & \multirow{2}{*}{$\begin{array}{c}\text { Light/capita }(\log ) \\
(5)\end{array}$} \\
\hline & $(1)$ & $(2)$ & (3) & $(4)$ & \\
\hline Time to nat. capital (log) & $\begin{array}{c}-1.987^{* * *} \\
(0.430)\end{array}$ & $\begin{array}{c}-2.581^{* * *} \\
(0.473)\end{array}$ & $\begin{array}{l}0.519^{* *} \\
(0.237)\end{array}$ & $\begin{array}{l}0.790^{* *} \\
(0.396)\end{array}$ & $\begin{array}{r}-0.031 \\
(0.040)\end{array}$ \\
\hline Time to reg. capital (log) & $\begin{array}{c}-1.403^{* * *} \\
(0.317)\end{array}$ & $\begin{array}{c}-1.527^{* * *} \\
(0.329)\end{array}$ & $\begin{array}{c}0.174 \\
(0.155)\end{array}$ & $\begin{array}{c}0.229 \\
(0.342)\end{array}$ & $\begin{array}{c}-0.089^{* *} \\
(0.036)\end{array}$ \\
\hline$\beta_{1}+\beta_{2}:$ & $\begin{array}{c}-3.39^{* * *} \\
(0.487)\end{array}$ & $\begin{array}{c}-4.108^{* * *} \\
(0.531)\end{array}$ & $\begin{array}{l}0.694^{* * *} \\
(0.265) \\
\end{array}$ & $\begin{array}{l}1.019^{* *} \\
(0.505)\end{array}$ & $\begin{array}{r}-0.12^{* *} \\
(0.048)\end{array}$ \\
\hline Weights & country & $\begin{array}{l}\text { country } \\
\text { cohort }\end{array}$ & country & $\begin{array}{l}\text { country } \\
\text { cohort }\end{array}$ & population \\
\hline Point FE: & yes & yes & yes & yes & yes \\
\hline Country-year FE: & yes & yes & yes & yes & yes \\
\hline Survey FE: & yes & yes & - & & \\
\hline Controls: & yes & yes & - & & \\
\hline Mean DV: & 70 & 70 & 9.6 & 9.6 & -6.5 \\
\hline Observations & $2,091,736$ & $2,091,736$ & $2,895,564$ & $2,895,564$ & $1,507,013$ \\
\hline Adjusted $\mathrm{R}^{2}$ & 0.436 & 0.434 & 0.053 & 0.164 & 0.949 \\
\hline
\end{tabular}

Notes: OLS linear models. Individuals are the units of the education and infant mortality analyses, Voronoi cells those of the nightlight analyses. Control variables for models with primary education as the dependent variable consist of responents' age and age squared, as well as a female dummy. Where infant mortality is the dependent variable, models include an infant's mother's age at birth and its square, the birthorder and its square, as well as a female and twin dummy. Standard errors clustered on the point and country-year levels. Significance codes: ${ }^{*} \mathrm{p}<0.1{ }^{* *} \mathrm{p}<0.05 ;{ }^{* * *} \mathrm{p}<0.01$

Varying the size of Voronoi units: This last robustness check assesses the impact of the choice of the size of Voronoi units used in the baseline analysis $\left(400 \mathrm{~km}^{2}\right)$. Figure A17 plots the results of the baseline specification estimated with units with exponential increases in their size from 100 to $6400 \mathrm{~km}^{2}$. Reassuringly, the Figure shows that small units generally give rise to smaller estimated and standardized effects. The increases in the respective effects that comes with larger units might be due to the unit constant added to the nightlight measure, which has a larger effect in small units in which more units have no observed nightlight emissions. Throughout, decreases in travel times to regional cap-

\footnotetext{
${ }^{31}$ Because of the sampling scheme of the DHS and attrition-by-death, cohorts close to the date of the survey are bigger than those in the past.
} 
itals are associated with more nightlights. Decreases in travel times to national capitals are only associated with more nightlights in large units. This result adds to the uncertainty discussed in the main text on whether travel times to national capitals are indeed related to local nightlight emissions or not.

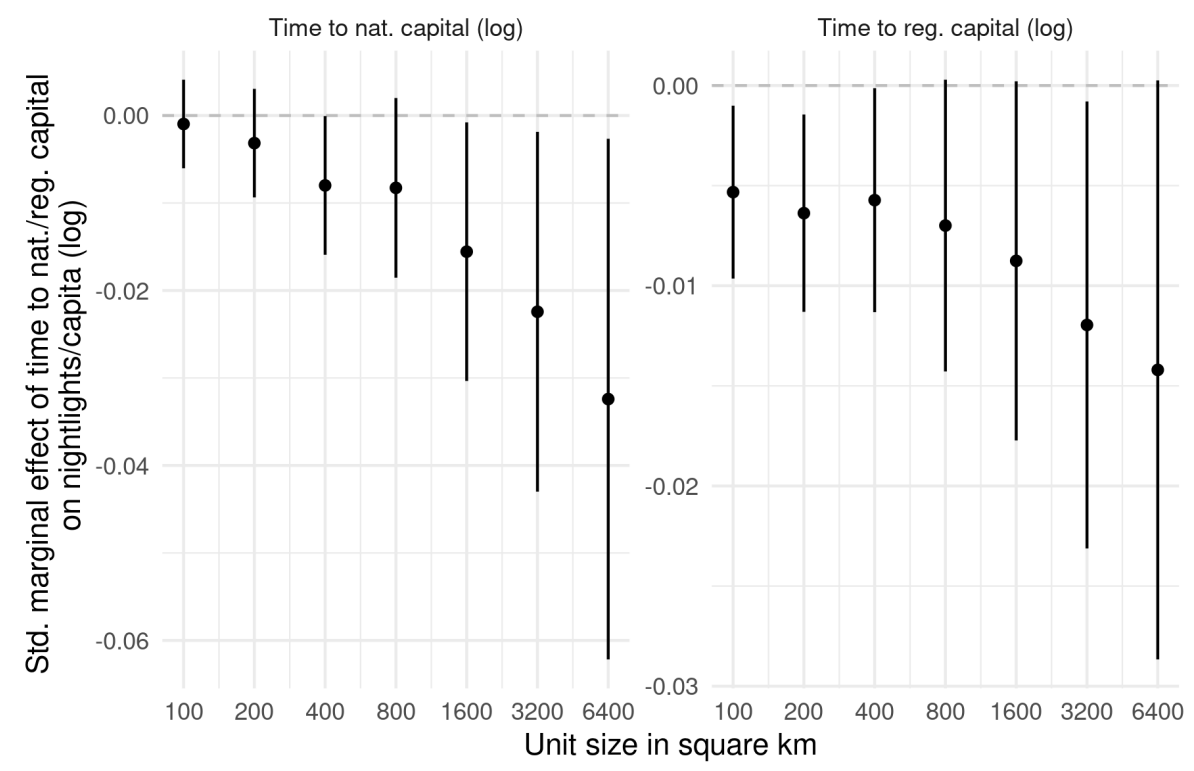

Figure A17: Effect of travel times to national and regional capitals on nightlight emissions in Voronoi units of increasing size.

Estimated coefficients and their 95\% CI are standardized by dividing them by the mean dependent variable $(\log (.001+$ nightlight p.c. $))$. 


\section{F References}

Afrobarometer. 2018. "Afrobarometer Data." Available at http://www.afrobarometer.org .

Ben Yishay, Ariel Rotberg, Renee, Jessica Wells, Zhonghui Lv, Seth Goodman, Lidia Kovacevic and Dan Runfola. 2017. Geocoding Afrobarometer Rounds 1-6: Methodology and Data Quality. Williamsburg, VA: AidData.

Burgess, Robin, Remi Jedwab, Edward Miguel, Ameet Morjaria and Gerard Padró i Miquel. 2015. "The value of democracy: Evidence from road building in Kenya." American Economic Review 105(6):1817-1851.

Donaldson, Dave. 2018. "Railroads of the Raj: Estimating the Impact of Transportation Infrastructure." American Economic Review 108(4-5):899-934.

Donaldson, Dave and Richard Hornbeck. 2016. "Railroads and American Economic Growth: A “Market Access" Approach." Quarterly Journal of Economics 131(2):799-858.

Eaton, Jonathan and Samuel Kortum. 2002. "Technology, Gravity, and Trade." Econometrica 70(5):1741-1779.

FAO. 2014. "Global Administrative Unit Layers." Available from: http://data.fao.org/map?entryId=f7e7adb0-88fd-11da-a88f-000d939bc5d8Etab=metadata

Fesler, James. 1949. Area and Administration. Birmingham: University of Alabama Press.

Franck, Raphaël and Ilia Rainer. 2012. "Does the Leader's Ethnicity Matter? Ethnic Favoritism, Education, and Health in Sub-Saharan Africa." American Political Science Review 106(2):294-325.

Goldewijk, Kees Klein, Arthur Beusen and Peter Janssen. 2010. “Long-term dynamic modeling of global population and built-up area in a spatially explicit way: HYDE 3.1." The Holocene 2010(1):1-9.

Gottlieb, Jessica, Guy Grossman, Horacio Larreguy and Benjamin Marx. 2019. "A Signaling Theory of Distributive Policy Choice: Evidence from Senegal." Journal of Politics 81(2):631-647.

Green, Elliott. 2010. "Patronage, district creation, and reform in Uganda." Studies in Comparative International Development 45(1):83-103.

Grossman, Guy, Jan H. Pierskalla and Emma Boswell Dean. 2017. “Government Fragmentation and Public Goods Provision." Journal Of Politics 79(3):823-839.

Grossman, Guy and Janet I. Lewis. 2014. "Administrative Unit Proliferation." American Political Science Review 108(01):196-217. 
Hassan, Mai. 2016. "A State of Change: District Creation in Kenya after the Beginning of Multi-party Elections." Political Research Quarterly 69(3):510-521.

Herbst, Jeffrey. 2000. States and Power in Africa. Princeton: Princeton University Press.

Hodler, Roland and Paul A. Raschky. 2014. "Regional Favoritism." The Quarterly Journal of Economics 129(2):995-1033.

Jedwab, Remi and Adam Storeygard. 2018. “The Average and Heterogeneous Effects of Transportation Investments: Evidence from Sub-Saharan Africa 1960-2010." Unpublished Working Paper.

Jedwab, Remi and Alexander Moradi. 2016. "The Permanent Effects of Transportation Revolutions in Poor Countries: Evidence from Africa." Review of Economics and Statistics 98(2):268-284.

Lloyd, Stuart P. 1982. "Least Squares Quantization in PCM." IEEE Transactions on Information Theory 28(2):129-137.

Miguel, Edward. 2004. "Tribe or Nation? Nation Building and Public Goods in Kenya versus Tanzania." World Politics 56(April 2004):328-362.

Müller-Crepon, Carl, Philipp Hunziker and Lars-Erik Cederman. 2021. "Roads to Rule, Roads to Rebel: Relational State Capacity and Conflict in Africa." Journal of Conflict Resolution 65(2-3):563-590.

Polsby, Daniel D. and Robert Popper. 1991. "The Third Criterion: Compactness as a Procedural Safeguard Against Partisan Gerrymandering." Yale Law \& Policy Review 9(2):301-353.

Resnick, Danielle. 2017. “Democracy, decentralization, and district proliferation: The case of Ghana." Political Geography 59:47-60.

Scott, James C. 2017. Against the Grain. A Deep History of the Earliest States. New Haven: Yale University Press.

Shelhamer, Evan, Jonathan Long and Trevor Darrell. 2017. "Fully Convolutional Networks for Semantic Segmentation." IEEE Transactions on Pattern Analysis and Machine Intelligence 39(4):640-651.

Vogt, Manuel, Nils-Christian Bormann, Seraina Rüegger, Lars-Erik Cederman, Philipp M Hunziker and Luc Girardin. 2015. "Integrating Data on Ethnicity, Geography, and Conflict: The Ethnic Power Relations Dataset Family." Journal of Conflict Resolution 59(7):1327-1342.

Weidmann, Nils and Kristian Skrede Gleditsch. 2010. "Mapping and Measuring Country Shapes: The cshapes Package." R Journal 2(1):18-24. 
World Bank. 2018. "World Development Indicators." Accessed on 2019/03/20 from https://databank.worldbank.org/data . 